University of Nebraska - Lincoln

DigitalCommons@University of Nebraska - Lincoln

Publications from USDA-ARS / UNL Faculty

U.S. Department of Agriculture: Agricultural

Research Service, Lincoln, Nebraska

2011

Soil Management Implications of Producing Biofuel Feedstock

Jane M. F. Johnson

USDA-ARS, Jane.johnson@ars.usda.gov

David W. Archer

USDA-ARS

Douglas L. Karlen

USDA-ARS, doug.karlen@ars.usda.gov

Sharon L. Weyers

USDA-ARS

Wally W. Wilhelm

USDA-ARS

Follow this and additional works at: https://digitalcommons.unl.edu/usdaarsfacpub

Johnson, Jane M. F.; Archer, David W.; Karlen, Douglas L.; Weyers, Sharon L.; and Wilhelm, Wally W., "Soil Management Implications of Producing Biofuel Feedstock" (2011). Publications from USDA-ARS / UNL Faculty. 1380.

https://digitalcommons.unl.edu/usdaarsfacpub/1380

This Article is brought to you for free and open access by the U.S. Department of Agriculture: Agricultural Research Service, Lincoln, Nebraska at DigitalCommons@University of Nebraska - Lincoln. It has been accepted for inclusion in Publications from USDA-ARS / UNL Faculty by an authorized administrator of DigitalCommons@University of Nebraska - Lincoln. 


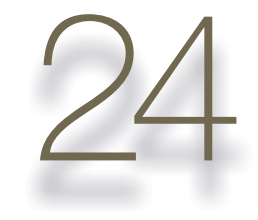

\title{
Soil Management Implications of Producing Biofuel Feedstock
}

\author{
Jane M.F. Johnson, David W. Archer, Douglas L. Karlen, \\ Sharon L. Weyers, and Wally W. Wilhelm
}

$\mathrm{T}$

he use of plant biomass for energy has existed since humans mastered the use of fire, although utilization beyond the open fire has evolved. The concept of using recent biomass as a major energy feedstock is being revisited, driven by high consumer demand (growing population), declining domestic oil supplies, increasing cost of fossil fuels, and a desire to curb the emission of greenhouse gases (Johnson et al., 2007b). In general terms, agriculture and forestry are the economic sectors commercially producing a wide array of bioenergy feedstocks (e.g., grains, herbaceous annuals, herbaceous perennials, and woody perennials). For this review, biomass feedstock is any nongrain, plant-derived feedstock. These commodities can serve as feedstock for cellulosic ethanol or other thermochemical platforms such as gasification or pyrolysis.

The type of bioenergy feedstock produced and the desired energy product can alter the management implications, which likely will vary by region. It is also likely that a given farm operation may produce multiple feedstocks, including corn and soybean grain, perennial grasses, and crop residues. The potential risks and benefits of growing and using feedstocks vary considerably (Johnson et al., 2007b). The challenge of establishing a perennial biomass system depends on prior management. Conversion of highly diverse grassland systems to low-diversity or monoculture perennial systems could reduce the environmental benefits of these lands. Conversely, converting from high-input, annual crop species to perennial species could reduce input requirements (fertilizer, fuel, pesticides) and reduce erosion risks, and thus have positive environmental impacts (Mann and Tolbert, 2000). Agronomic, environmental, and economic issues need to be addressed for the wide range of feedstocks and feedstock combinations to assure sustainability.

Agronomic management of the major cash crops, i.e., corn (Zea mays L.), soybean (Glycine max L. [Merr.]), wheat (Triticum aestivum L.), and rice (Oryza sativa L.), has been studied for many decades. However, changes in traditional management strategies and practices are necessary when crop residues such as stover or straw are harvested routinely. Answers to the following questions will provide the framework for making these changes: (i) how much biomass can be harvested without exacerbating soil erosion or loss of soil organic matter (SOM) and soil organic carbon (SOC),

J.M.F. Johnson (Jane.johnson@ars.usda.gov) and S.L. Weyers, USDA-Agricultural Research Service, 803 lowa Ave., Morris, MN 56267; D.W. Archer, USDA-Agricultural Research Service, 1701 10th Ave. SW, P.O. Box 459, Mandan, ND 58554; D.L. Karlen, USDA-Agricultural Research Service National Laboratory for Agriculture and the Environment, 2110 University Blvd., Ames, IA 50011; W.W. Wilhelm, deceased, formerly USDA-ARS, University of Nebraska, Lincoln. The U.S. Department of Agriculture offers its programs to all eligible persons regardless of race, color, age, sex, or national origin, and is an equal opportunity employer.

doi:10.2136/2011.soilmanagement.c24

Copyright $\odot$ 2011. American Society of Agronomy and Soil Science Society of America, 5585 Guilford Road, Madison, WI 53711, USA. Soil Management: Building a Stable Base for Agriculture. Jerry L. Hatfield and Thomas J. Sauer (ed.) 
(ii) how will harvesting biomass impact fertility management, (iii) how often should the biomass be harvested, (iv) how can perennial biomass crops be integrated into a current farming system, (v) can tillage be reduced when residues are harvested, and (vi) how will the residue be harvested, stored, and transported? Furthermore, utilization of new or alternative crops has agronomic unknowns such as pesticide and fertility management, and economic questions such as market demand. The risks to farmers can be high due to lack of agronomic experience, uncertain markets, and lack of crop insurance or subsidies.

Many aspects of crop residue management were reviewed in the ASA Special Publication Number 31, edited by W. R. Oschwald et al. (1978). Although 30 years have passed since it was published, many of the principles addressed are still relevant: conservation, soil erosion control, soil chemistry, disease, and weed control. This review focuses on preventing soil erosion, maintaining or building SOM, and managing nutrients and water for agricultural

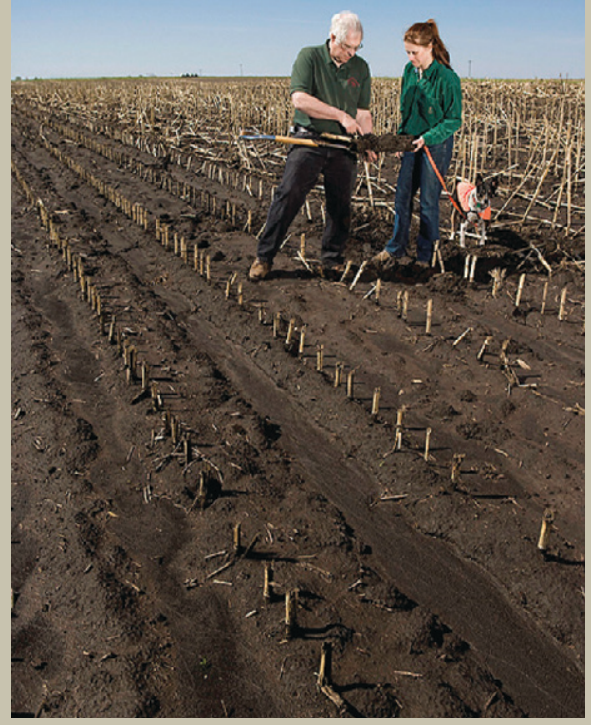

Fig. 24|1. A visual assessment of soil quality impacts of harvesting corn stover. Notice the soil erosion in the foreground following intense spring rains where corn stover had been harvested during the previous autumn (ARS Photo d1235-30). commodity crops, herbaceous annuals, and perennials. It also includes a discussion of economic influences on management in biofuel feedstock production.

\section{Soil Erosion and Soil Organic Carbon}

Many soil conservation improvements have been realized by using the tolerable annual soil loss (T) concept, which was incorporated into the United States' conservation policies (USDA-NRCS, 2006). Soil erosion predictive models, the Revised Universal Soil Loss Equation version 2 (RUSLE2) and the Wind Erosion Equation (WEQ), have been widely used by the USDA-NRCS as planning tools to control soil erosion to T or below (Cox, 2008). However, these tools alone do not address loss of SOC. The USDA-NRCS estimated that managing soil to maintain SOC could save an additional 1.2 billion $\mathrm{Mg}$ of soil and 8.2 billion U.S. dollars annually (http://soils. usda.gov/sqi/concepts/soil_organic_matter/ som_manage.html, verified 16 Sept. 2010). Safeguarding soil productivity in an era of biomass feedstock harvest and competing demands for agricultural production is paramount (Lal, 2004; Wilhelm et al., 2004; Graham et al., 2007; Johnson et al., 2007b).

No-tillage farming retains all unharvested crop residues on the soil surface, dramatically reducing soil erosion. Both the Perlack et al. (2005) and Graham et al. (2007) assessments of harvestable biomass assume universal conversion to no-tillage farming systems. Unfortunately, it is unlikely that no-tillage farming will be adopted universally. In northern states such as Minnesota, less than 5\% of the cropland is managed using no-tillage; although about $50 \%$ of the acreage has some form of conservation tillage (chisel plow, ridge tillage, or mulch tillage) (CTIC, 2002). The low adoption rate in the northern tier states is related to the short growing season and cool, wet springs. Tillage aids in drying and warming soil, especially in early spring. In drier climates, retaining residue on the soil surface by eliminating tillage is a strategy to reduce evaporation (Al-Darby et al., 1989) and to improve crop productivity (Wilhelm et al., 1986). Unfortunately, harvesting biomass reduces the effectiveness of conservation- or no-tillage to retard erosion (Fig. 24|1).

Policy and conservation guidelines for minimizing erosion already exist and are 
applicable to biomass harvest; however, these guidelines may not be sufficient to maintain SOC. Wilhelm et al. (2007) found that the residue requirements for maintaining SOC exceeded those needed to limit erosion at or below T (Fig. 24/2). Thus, developing harvest recommendations constrained only for erosion control risks loss of SOC. Part of the challenge in developing guidelines that address both erosion and SOC is that mechanisms controlling soil erosion differ from managing SOC (Wilhelm et al., 2004). Reducing erosion is a function of percent soil coverage (Stocking, 1988; Bilbro and Fryrear, 1994), but maintaining SOC requires biomass inputs equal biomass outputs.

Using empirical data and linear regression between $\mathrm{C}$ inputs and change in SOC, Johnson et al. (2006a) proposed the term "minimum source C (MSC)," which is the annual $\mathrm{C}$ inputs necessary to maintain SOC content. Based on literature data for several crops and tillage practices, Johnson et al. (2006a) estimated an average MSC at $2.21 \pm$ 1.1 $\mathrm{Mg} \mathrm{C} \mathrm{ha} \mathrm{yr}^{-1}(n=21)$. Since the Johnson et al. (2006a) review, several other studies reported empirical MSC estimates ranging from 0.032 to $8.7 \mathrm{Mg} \mathrm{C} \mathrm{ha-1} \mathrm{yr}^{-1}$ (Table 24I1). Wheat tends to have lower MSC compared with corn or soybean systems, perhaps because wheat-based systems are more common in cooler, dryer climates. Banowetz et al. (2008) using the USDA-NRCS Soil Conditioning Index (SCI) predicted a MSC of 2.0 $\mathrm{Mg} \mathrm{C} \mathrm{ha-1} \mathrm{for} \mathrm{cereal} \mathrm{crops} \mathrm{and} \mathrm{seed} \mathrm{grass} \mathrm{in}$ Washington. Theoretically, once MSC for a given management system is known, the

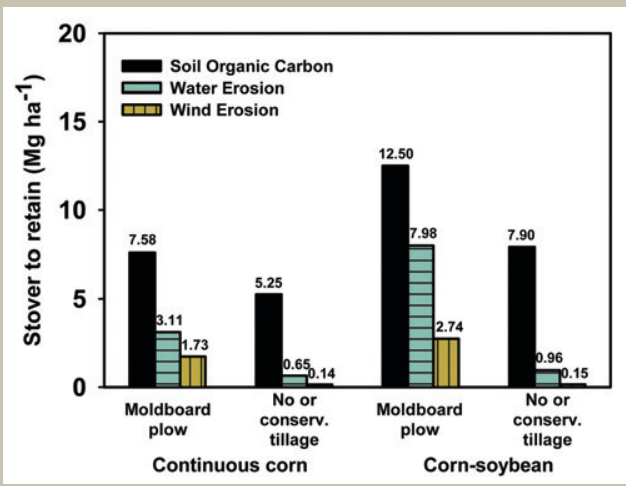

Fig. 24|2. Tillage and crop rotation effects on the annual average amount of corn stover required for protecting soil resources against wind or water erosion and to sustain soil carbon (organic matter) levels (Wilhelm et al., 2007).

amount of sustainably harvestable biomass can be predicted. However, not all empirical studies of SOC demonstrate a correlation with C inputs (Dexter et al., 1982; Johnson and Chamber, 1996; Nicholson et al., 1997; Sainju et al., 2006b; Huggins et al., 2007); in such cases, MSC cannot be estimated. A lack of correlation to $\mathrm{C}$ inputs indicates that either the rate of humification and/or the rate of mineralization were changing (Bayer et al., 2006). Based on the wide range in MSC reported and the examples where MSC cannot be estimated we suggest that additional research and modeling efforts are needed to

Table 24|1. Recent empirical estimates on the amount of annual aboveground non-grain $\mathrm{C}$ inputs required for maintaining soil organic $\mathrm{C}$ levels.

\begin{tabular}{|c|c|c|c|c|c|}
\hline Location & Cropt & Primary tillage $\neq$ & Soil type§ & C & Citation \\
\hline & & & & $\mathrm{Mg} \mathrm{ha}^{-1} \mathrm{yr}^{-1}$ & \\
\hline SD & M & $\mathrm{CP}$ & L & 3.21 & Pikul et al. (2008) \\
\hline NE & $M, S$ & D & SiL & 2.4 & Varvel and Wilhelm (2008a) \\
\hline MN & $M, S$ & NT & $C L$ & 8.7 & Huggins et al. (2007) \\
\hline MT & W & NT & $\mathrm{CL}$ & 0.82 & Sainju et al. (2006a) \\
\hline CA & W, M, T & CT & SiL, SiCL & 2.6 & Kong et al. (2005) \\
\hline India & W, S & NR & SaL & 0.032 & Kundu et al. (2007) \\
\hline Brazil & $\mathrm{O}, \mathrm{M}, \mathrm{V}, \mathrm{C}$ & CT & $\mathrm{SaCl}$ & 6.2 & Bayer et al. (2006) \\
\hline Brazil & $\mathrm{O}, \mathrm{M}, \mathrm{V}, \mathrm{C}$ & NT & $\mathrm{SaCL}$ & 2.7 & Bayer et al. (2006) \\
\hline
\end{tabular}

† C, cowpea [Vigna unguiculata (L.) Walp.]; M, maize (corn); O, oat (Avena strigosa Schreb.); S, soybean; T, tomato (Lycopersicon esculentum Mill.); V, vetch (Vicia sativa L.); W, wheat.

‡ CP, chisel plow; CT, conventional tillage, details not provided; D, disk; NR, not reported; NT, no-tillage.

$\S \mathrm{Si}$, silt; Sa, sandy; L, loam; C, clay. 
more accurately predict harvest rates that will not degrade SOC.

Currently, the USDA-NRCS SCI tool provides a user-friendly, accessible means for estimating if harvesting a chosen amount of biomass would likely cause a loss of SOC. The SCI has three primary components: (i) plant biomass input or removal rate, (ii) effect of tillage and management on organic matter decomposition, and (iii) erosion prediction based on management. The tool does not give an amount of $C$ sequestered or lost, but provides guidance on the direction of change. Additional scientific review and validation is needed to expand its validity to a wider variety of agricultural regions and management practices including irrigated systems and nontraditional cropping systems (Cox, 2008). The data tables within SCI are updated as new information becomes available (USDA-NRCS, 2002). Other models, such as CQSTR (Rickman et al., 2001), EPIC (Izaurralde et al., 2006), CENTURY (Parton et al., 1988), and DAISY (Bruun et al., 2003) offer additional tools for predicting the impact of biomass harvest on SOC, but are more complicated, requiring more input data and more knowledge for interpretation.

Management strategies for preventing SOC loss and controlling wind and water erosion should be included whenever biomass feedstocks (annual or perennial) are harvested. Strategies may include one or more of the following management modifications: (i) reducing or eliminating soil tillage, (ii) maintaining adequate soil cover, (iii) adding perennial crops into the rotation, and (iv) using green manures, cover crops, and/or living mulches (Syers, 1997; Thorup-Kristensen et al., 2003; Johnson et al., 2007b; Johnson et al., 2007c). Reducing or eliminating tillage is well known for keeping crop residue on the soil surface (e.g., Siemens and Oschwald, 1978). Herbaceous perennials typically have extensive root systems, which can increase SOC while helping protect the soil from erosive forces (McLaughlin and Walsh, 1998; Frank et al., 2004; Liebig et al., 2005; Lee et al., 2007; Liebig et al., 2008). Thus, inclusion of a perennial into a rotation is a strategy to offset SOC loss during rotation phases that return less $\mathrm{C}$ into the soil. Green manures have been used as biological tools for $\mathrm{N}$ management, erosion control, and to increase SOC (Thorup-Kristensen et al., 2003). Cover crops, which are more commonly used in warmer, wetter climates (Dabney et al., 2001), protect the soil from erosive forces, suppress weeds, help manage $\mathrm{N}$ fertility, and increase $\mathrm{C}$ input by extending the growing season (Reicosky and Forcella, 1998; Dabney et al., 2001; Thorup-Kristensen et al., 2003; Singer, 2005; Baker et al., 2007).

\section{New and Alternative Crops}

Many perennial grass species can serve as biomass feedstocks (Jasinskas et al., 2008; Monti et al., 2008; Mulkey et al., 2008). However, greater emphasis has been placed on developing switchgrass (Panicum virgatum L.) and miscanthus (Miscanthus xgiganteus J. M. Greef \& Deuter ex Hodk. \& Renvoize), for feedstock production (Wright, 1994; Heaton et al., 2008). Switchgrass has a long history as a forage crop (Moser and Vogel, 1995; Wolf and Fiske, 1996; Vogel et al., 1999). Therefore, multiple cultivars (Cassida et al., 2005b; Adler et al., 2006) and agronomic recommendations for switchgrass are available in several regions (Wolf and Fiske, 1996; Teel et al., 2003; Lee and Boe, 2005; Nyoka, 2007). Research is ongoing to improve breeding, production, and management to improve switchgrass and other grasses (McLaughlin and Adams Kszos, 2005; Heaton et al., 2008; Lemus et al., 2008).

Additional bioenergy resources are also in development. Several oilseed crops are being explored for biodiesel production, for industrial products (e.g., lubricants and plasticizers), and even for jet fuel (Table $24 \mid 2)$, depending on the conversion process utilized. Many of the oilseed crops have oil contents as high as or higher than soybean, and can be grown on marginal land with fewer inputs than soybean. One example is cuphea (Cuphea spp.), which is only semidomesticated, with an indeterminate growth habit, and shattering problems that need to be resolved through improved plant breeding (Knapp and Crane, 2000; Gesch et al., 2006). Currently, alternative oilseed crop expansion in the United States is hampered by lack of markets, subsidies, and crop insurance (Johnson et al., 2007b). In addition, agronomic management tools (e.g., nutrient and pesticide recommendations, rotations, harvest strategies) are needed. 
Table 24|2. Alternative oilseed crops in production or development.

\begin{tabular}{|c|c|c|c|c|}
\hline Common name & Scientific name & Potential use & $\begin{array}{l}\text { Commercially } \\
\text { grown }\end{array}$ & Citation \\
\hline Oilseed rape & Brassica napus L. & biodiesel & yes & Demirbas (2006) \\
\hline Crambe & $\begin{array}{l}\text { Crambe abyssinica Hochst. } \\
\text { ex R. E. Fr. }\end{array}$ & lubricants, plasticizers & yes & Carlson et al. (1996) \\
\hline Lesquerella & $\begin{array}{l}\text { Lesquerella fendleri (A. Gray) } \\
\text { S. Watson }\end{array}$ & lubricants, plasticizers & no & $\begin{array}{l}\text { Carlson et al. (1996); Dierig et } \\
\text { al. (1996) }\end{array}$ \\
\hline Camelina & Camelina sativa (L.) Crantz & industrial use & yes & Putnam et al. (1993) \\
\hline Pennycress & Thlaspi arvense L. & cover crop, biodiesel & no & Johnson et al. (2007b) \\
\hline Castor-bean & Ricinus cummunis L. & lubricant & yes & $\begin{array}{l}\text { Brigham (1993); Goodrum and } \\
\text { Geller (2005) }\end{array}$ \\
\hline Cuphea & Cuphea spp. & $\begin{array}{l}\text { biodiesel, } \\
\text { jet fuel, lubricant }\end{array}$ & yes & Gesch et al. (2006) \\
\hline
\end{tabular}

\section{Nutrient Management}

Adaptation of current cropping systems for biomass harvest and development of dedicated biomass crops raise nutrient management questions such as: (i) amount of various nutrients actually removed, (ii) impact of removal on soil fertility, (iii) management strategies to replace or reduce nutrient removal, and (iv) economics of nutrient replacement (discussed in economic section below). Harvesting annual crop residue in addition to grain removes additional nutrients; thus nutrient management may need to be adjusted. Likewise, nutrient management in perennial systems will need to be modified to reflect change in commodity from forage, such as alfalfa (Medicago spp.) or mixed hay to biomass feedstock. Historically, these species have been grown in pastures for grazing, harvested for hay or silage production, grown in Conservation Reserve Program (CRP) land, or grown in other conservation areas such as grassy waterways. Perennials in conservation programs were rarely, if ever, harvested, while forage crops are managed for high feed value (protein and energy content) and generally harvested several times each year. As a biomass feedstock, energy or carbohydrate content is more important than protein. This difference in end use means that all aspects of nutrient management likely will be substantially different.

Nutrient concentration varies among crop species, plant organ, and physiological stage (Lewandowski and Kicherem, 1997; Fageria, 2004; Johnson et al., 2007a; Monti et al., 2008). The concentration averaged across all feedstocks and organs was $9.1 \pm 6.8 \mathrm{~g} \mathrm{~N}$ $\mathrm{kg}^{-1}, 0.9 \pm 0.5 \mathrm{~g} \mathrm{P} \mathrm{kg}^{-1}$, and $8.7 \pm 7.3 \mathrm{~g} \mathrm{~K} \mathrm{~kg}^{-1}$
(Table 24|3). Annuals crops did not appear to have different concentrations of N, P, or $\mathrm{K}$ compared with perennial species. Corn stems and cobs had lower nutrient concentration than corn leaves. Among these studies, cobs and switchgrass stems had the lowest concentration of N, switchgrass and miscanthus stems had the lowest concentration of $\mathrm{P}$, while giant reed grass stems (Arundo donax L.) had the lowest concentration of K. Feedstock likely will be harvested when it is relatively dry, thus nutrient concentrations will be lower than if the same feedstock were harvested for animal feed (Lewandowski and Kicherem, 1997; Reynolds et al., 2000; Hoskinson et al., 2007). Other macronutrients $(\mathrm{Ca}, \mathrm{Mg}$, and $\mathrm{S})$ and micronutrients $(\mathrm{B}, \mathrm{Cu}, \mathrm{Fe}, \mathrm{Mn}$, and $\mathrm{Zn})$ are also removed when biomass feedstocks are harvested (Fageria, 2004; Hoskinson et al., 2007; Monti et al., 2008). Therefore, producers will need to monitor soil fertility, scout crops for deficiency symptoms, and apply appropriate fertilizer mixtures as necessary.

Nutrient removal depends both on concentration and harvest rate. Therefore, if a feedstock removes $7.1 \mathrm{~g} \mathrm{~N} \mathrm{~kg}^{-1}$ dry biomass and $5 \mathrm{Mg} \mathrm{ha}^{-1}$ is harvested annually, then $35.5 \mathrm{~kg} \mathrm{~N} \mathrm{ha}^{-1}$ would be removed; similarly, $10 \mathrm{Mg}$ feedstock ha ${ }^{-1}$ removes $71 \mathrm{~kg} \mathrm{~N}$ $\mathrm{ha}^{-1}$. In the Pacific Northwest, switchgrass yielding 14 to $20 \mathrm{Mg} \mathrm{ha}^{-1}$ exports about 210 $\mathrm{kg} \mathrm{N} \mathrm{ha}{ }^{-1}, 40 \mathrm{~kg} \mathrm{P} \mathrm{ha}^{-1}$, and $350 \mathrm{~kg} \mathrm{~K} \mathrm{ha}^{-1}$ with harvested biomass (Hal Collins, personal communication). Duffy and Nanhou (2001) estimated $0.42 \mathrm{~kg} \mathrm{P} \mathrm{Mg}^{-1}$ and $9.4 \mathrm{~kg}$ $\mathrm{K} \mathrm{Mg}^{-1}$ were removed with every $\mathrm{Mg}$ of switchgrass harvested in the fall, which corresponds to $5.2 \mathrm{~kg} \mathrm{P} \mathrm{ha}^{-1}$ and $125 \mathrm{~kg} \mathrm{~K}$ $\mathrm{ha}^{-1}$ removed at a harvest rate of $13.4 \mathrm{Mg} \mathrm{ha}^{-1}$. 
Table 24|3. Plant concentration of N, P and K of potential annual and herbaceous perennial biomass feedstocks.

\begin{tabular}{|c|c|c|c|c|c|}
\hline Crop organ & $\mathrm{N}$ & $\mathrm{P}$ & $\mathrm{K}$ & Comment & Citation \\
\hline \multicolumn{6}{|l|}{ Annual crops } \\
\hline Barley straw & 6.4 & nrt & $\mathrm{nr}$ & & Cookson et al. (1998) \\
\hline Barley straw & 6.1 & $\mathrm{nr}$ & $\mathrm{nr}$ & & Andren and Paustian (1987) \\
\hline Barley straw & 6.0 & $\mathrm{nr}$ & $\mathrm{nr}$ & & Christensen (1986) \\
\hline Barley straw & 7.5 & 1.1 & 12.5 & & Lindstrom (1986) \\
\hline Barley straw & 7.9 & $\mathrm{nr}$ & $\mathrm{nr}$ & & Mitchell et al. (2001) \\
\hline Barley straw & 6.3 & $\mathrm{nr}$ & $\mathrm{nr}$ & & Velthof et al. (2002) \\
\hline Barley straw & 4.8 & $\mathrm{nr}$ & $\mathrm{nr}$ & avg. 3 yr and treatments & Halvorson and Reule (2007) \\
\hline Corn cob & 3.3 & $\mathrm{nr}$ & $\mathrm{nr}$ & & Burgess et al. (2002) \\
\hline Corn cob & 3.8 & $\mathrm{nr}$ & $\mathrm{nr}$ & & Halvorson and Johnson (2009) \\
\hline Corn cob & 10.0 & $\mathrm{nr}$ & $\mathrm{nr}$ & & Yu et al. (2008) \\
\hline Corn leaf & 10.3 & $\mathrm{nr}$ & $\mathrm{nr}$ & & Burgess et al. (2002) \\
\hline Corn leaf & 13.6 & $\mathrm{nr}$ & $\mathrm{nr}$ & & Johnson et al. (2007a) \\
\hline Corn stem & 5.7 & $\mathrm{nr}$ & $\mathrm{nr}$ & & Burgess et al. (2002) \\
\hline Corn stover & 5.9 & $\mathrm{nr}$ & $\mathrm{nr}$ & & Johnson et al. (2007a) \\
\hline Corn stover & 3.4 & 1.0 & 3.4 & & Breakwell and Turco (1989) \\
\hline Corn stover & 10.0 & 1.33 & 20.6 & & Tian et al. (1992) \\
\hline Corn stover & 5.7 & $\mathrm{nr}$ & $\mathrm{nr}$ & avg. of treatments & Al-Kaisi et al. (2005) \\
\hline Corn stover & 6.7 & $\mathrm{nr}$ & $\mathrm{nr}$ & & Burgess et al. (2002) \\
\hline Corn stover & 7.7 & 0.9 & 11.7 & $130 \mathrm{~d}$ after planting & Fageria (2004) \\
\hline Corn stover & 7.5 & 0.7 & 10.0 & avg. of cutting heights & Hoskinson et al. (2007) \\
\hline Corn stover & 11.1 & 1.8 & 13.3 & & Lindstrom (1986) \\
\hline Corn stover & 8.0 & 2.0 & $\mathrm{nr}$ & & Manlay et al. (2002) \\
\hline Corn stover & 7.3 & $\mathrm{nr}$ & $\mathrm{nr}$ & & Velthof et al. (2002) \\
\hline Millet straw $\neq$ & 2.7 & 0.7 & $\mathrm{nr}$ & & Manlay et al. (2002) \\
\hline Millet straw & 10.0 & 1.0 & 12.8 & & Fatondji et al. (2006) \\
\hline Millet straw & 13.8 & $\mathrm{nr}$ & $\mathrm{nr}$ & & Sarr et al. (2008) \\
\hline Rice hulls & 3.1 & 0.8 & 3.6 & & Linquist et al. (2007) \\
\hline Rice leaf & 26.0 & $\mathrm{nr}$ & $\mathrm{nr}$ & & Abiven et al. (2005) \\
\hline Rice leaf & 14.6 & $\mathrm{nr}$ & $\mathrm{nr}$ & avg. 10 cultivars & Ying et al. (1998) \\
\hline Rice stem & 10.0 & $\mathrm{nr}$ & $\mathrm{nr}$ & & Abiven et al. (2005) \\
\hline Rice stem & 6.2 & $\mathrm{nr}$ & $\mathrm{nr}$ & avg. 10 cultivars & Ying et al. (1998) \\
\hline Rice straw & 8.4 & 0.53 & 23.4 & & Tian et al. (1992) \\
\hline Rice straw & 6.5 & $\mathrm{nr}$ & $\mathrm{nr}$ & & Tirol-Padre et al. (2005) \\
\hline Rice straw & 5.0 & 0.5 & 31.0 & & Kaewpradit et al. (2008) \\
\hline Rice straw & 4.1 & 1.0 & $\mathrm{nr}$ & & Manlay et al. (2002) \\
\hline Sorghum leaf & 26.0 & $\mathrm{nr}$ & $\mathrm{nr}$ & & Abiven et al. (2005) \\
\hline Sorghum leaf & 13.5 & 1.3 & 10.2 & avg. among varieties & Monti et al. (2008) \\
\hline Sorghum straw & 6.2 & $\mathrm{nr}$ & $\mathrm{nr}$ & avg. among treatments & Franzluebbers et al. (1995) \\
\hline Sorghum straw & 7.0 & 0.5 & $\mathrm{nr}$ & & Saffigna et al. (1989) \\
\hline Sorghum stem & 9.0 & $\mathrm{nr}$ & $\mathrm{nr}$ & & Abiven et al. (2005) \\
\hline Sorghum stem & 3.5 & 0.7 & 12.8 & avg. among varieties & Monti et al. (2008) \\
\hline Soybean leaf & 34.0 & $\mathrm{nr}$ & $\mathrm{nr}$ & avg. 3 yr, Oct. harvest & Rao et al. (2005) \\
\hline Soybean leaf & 44.0 & $\mathrm{nr}$ & $\mathrm{nr}$ & & Abiven et al. (2005) \\
\hline Soybean leaf & 15.8 & $\mathrm{nr}$ & $\mathrm{nr}$ & & Johnson et al. (2007a) \\
\hline Soybean straw & 9.7 & $\mathrm{nr}$ & $\mathrm{nr}$ & & Al-Kaisi et al. (2005) \\
\hline Soybean straw & 12.8 & 1.5 & 15.2 & & Fageria (2004) \\
\hline Soybean straw & 14.8 & $\mathrm{nr}$ & $\mathrm{nr}$ & avg. among treatments & Franzluebbers et al. (1995) \\
\hline Soybean straw & 22.5 & 2.2 & 10.5 & & Lindstrom (1986) \\
\hline Soybean stem & 8.8 & $\mathrm{nr}$ & $\mathrm{nr}$ & avg. among treatments & Franzluebbers et al. (1995) \\
\hline Soybean stem & 7.0 & $\mathrm{nr}$ & $\mathrm{nr}$ & avg. 3 yr, Oct. harvest & Rao et al. (2005) \\
\hline
\end{tabular}




\section{Soil Management Practices}

\begin{tabular}{|c|c|c|c|c|c|}
\hline Crop organ & $\mathrm{N}$ & $\mathrm{P}$ & $\mathrm{K}$ & Comment & Citation \\
\hline & \multicolumn{3}{|c|}{$\longrightarrow \mathrm{g} \mathrm{kg}^{-1} \longrightarrow$} & & \\
\hline Soybean stem & 20.0 & $\mathrm{nr}$ & $\mathrm{nr}$ & & Abiven et al. (2005) \\
\hline Soybean stem & 4.4 & $\mathrm{nr}$ & $\mathrm{nr}$ & & Johnson et al. (2007a) \\
\hline Wheat leaf & 7.0 & $\mathrm{nr}$ & $\mathrm{nr}$ & & Abiven et al. (2005) \\
\hline Wheat straw & 5.9 & $\mathrm{nr}$ & $\mathrm{nr}$ & & Cookson et al. (1998) \\
\hline Wheat straw & 9.4 & 1.53 & 5.88 & & Borie et al. (2002) \\
\hline Wheat straw & 6.0 & $\mathrm{nr}$ & $\mathrm{nr}$ & avg. among treatments & Franzluebbers et al. (1995) \\
\hline Wheat straw & 10.6 & $\mathrm{nr}$ & $\mathrm{nr}$ & & Jawson and Elliott (1986) \\
\hline Wheat straw & 6.7 & 0.7 & 9.7 & & Lindstrom (1986) \\
\hline Wheat straw & 8.2 & $\mathrm{nr}$ & $\mathrm{nr}$ & & Mitchell et al. (2001) \\
\hline Wheat straw & 3.7 & $\mathrm{nr}$ & $\mathrm{nr}$ & & Tirol-Padre et al. (2005) \\
\hline Wheat straw & 6.2 & $\mathrm{nr}$ & $\mathrm{nr}$ & & Velthof et al. (2002) \\
\hline Wheat stem & 4.0 & $\mathrm{nr}$ & $\mathrm{nr}$ & & Abiven et al. (2005) \\
\hline Mean \pm Std. dev. & $9.9 \pm 7.5$ & $1.1 \pm 0.5$ & $13.1 \pm 7.6$ & & \\
\hline \multicolumn{6}{|l|}{ Perennial species } \\
\hline Cardoon leaf & 9.6 & 1.5 & 4.7 & 4-yr stand, after frost & Monti et al. (2008) \\
\hline Cardoon stem & 3.0 & 1.4 & 6.5 & 4-yr stand, after frost & Monti et al. (2008) \\
\hline $\begin{array}{l}\text { Reed Canary grass } \\
\text { straw }\end{array}$ & 11.7 & 1.4 & 3.0 & 3-yr stand, avg. 5 treatments & Katterer et al. (1998) \\
\hline $\begin{array}{l}\text { Giant reed } \\
\text { grass stem }\end{array}$ & 5.2 & 0.3 & 5.6 & 4-yr stand, after frost & Monti et al. (2008) \\
\hline $\begin{array}{l}\text { Giant reed } \\
\text { grass leaf }\end{array}$ & 15.7 & 0.8 & 5.1 & 4-yr stand, after frost & Monti et al. (2008) \\
\hline Miscanthus leaf & 6.3 & 0.4 & 3.3 & 4-yr stand, after frost & Monti et al. (2008) \\
\hline Miscanthus straw & 15.1 & $\mathrm{nr}$ & $\mathrm{nr}$ & year 1 fall harvest & $\begin{array}{l}\text { Clifton-Brown and Lewandowski } \\
\text { (2002) }\end{array}$ \\
\hline Miscanthus straw & 13.4 & $\mathrm{nr}$ & $\mathrm{nr}$ & year 1 spring harvest & $\begin{array}{l}\text { Clifton-Brown and Lewandowski } \\
\text { (2002) }\end{array}$ \\
\hline Miscanthus straw & 7.3 & $\mathrm{nr}$ & $\mathrm{nr}$ & $\begin{array}{l}\text { year } 2 \text { (avg. fall and spring } \\
\text { harvest) }\end{array}$ & $\begin{array}{l}\text { Clifton-Brown and Lewandowski } \\
\text { (2002) }\end{array}$ \\
\hline Miscanthus straw & 4.3 & $\mathrm{nr}$ & $\mathrm{nr}$ & $\begin{array}{l}\text { year } 3 \text { (avg. fall and spring } \\
\text { harvest) }\end{array}$ & $\begin{array}{l}\text { Clifton-Brown and Lewandowski } \\
\text { (2002) }\end{array}$ \\
\hline Miscanthus stem & 1.6 & 0.1 & 3.6 & 4-yr stand, after frost & Monti et al. (2008) \\
\hline Switchgrass straw & 13.6 & $\mathrm{nr}$ & $\mathrm{nr}$ & late summer & Johnson et al. (2007a) \\
\hline Switchgrass straw & 7.9 & 0.7 & 1.8 & 4-yr stand, after frost & Monti et al. (2008) \\
\hline Switchgrass straw & 5.3 & $\mathrm{nr}$ & $\mathrm{nr}$ & Nov., avg. treatment and year & Lemus et al. (2008) \\
\hline Switchgrass straw & 11.1 & $\mathrm{nr}$ & $\mathrm{nr}$ & Jul., avg. treatment and year & Lemus et al. (2008) \\
\hline Switchgrass straw & 4.5 & 0.9 & 3.4 & late frost & Adler et al. (2006) \\
\hline Switchgrass straw & 4.1 & 0.5 & 0.6 & early spring & Adler et al. (2006) \\
\hline Switchgrass straw & 5.4 & 0.4 & 9.4 & fall harvest & $\begin{array}{l}\text { Duffy and Nanhou (2001); Lemus et } \\
\text { al. (2002) }\end{array}$ \\
\hline Switchgrass straw & $\mathrm{nr}$ & 0.08 & 0.6 & spring harvest & Duffy and Nanhou (2001) \\
\hline Switchgrass straw & 11.2 & $\mathrm{nr}$ & $\mathrm{nr}$ & Sept. harvest, avg. 3 varieties & Bransby et al. (1998) \\
\hline Switchgrass straw & 6.0 & 0.9 & $\mathrm{nr}$ & $\begin{array}{l}\text { late fall harvest, avg. among } \\
\text { genotypes }\end{array}$ & Cassida et al. (2005a) \\
\hline Switchgrass straw & 6.3 & $\mathrm{nr}$ & $\mathrm{nr}$ & $\begin{array}{l}\text { late fall, avg. among varieties } \\
\text { and } \mathrm{N} \text { treatment }\end{array}$ & Madakadze et al. (1999) \\
\hline Switchgrass straw & 7.3 & $\mathrm{nr}$ & $\mathrm{nr}$ & summer harvest, avg. $5 \mathrm{yr}$ & Reynolds et al. (2000) \\
\hline Switchgrass straw & 3.6 & $\mathrm{nr}$ & $\mathrm{nr}$ & $\begin{array}{l}\text { fall harvest, avg. tillage } \\
\text { treatment and yr }\end{array}$ & Reynolds et al. (2000) \\
\hline Switchgrass straw & 18.1 & $\mathrm{nr}$ & $\mathrm{nr}$ & boot to inflorescence & Vogel et al. (2002) \\
\hline Switchgrass straw & 8.9 & $\mathrm{nr}$ & $\mathrm{nr}$ & post anthesis, avg. sites & Vogel et al. (2002) \\
\hline Switchgrass straw & 5.0 & $\mathrm{nr}$ & $\mathrm{nr}$ & after killing frost & Vogel et al. (2002) \\
\hline Switchgrass stem & 4.1 & $\mathrm{nr}$ & $\mathrm{nr}$ & late summer & Johnson et al. (2007a) \\
\hline Switchgrass stem & 3.2 & 0.3 & 3.1 & 4-yr stand, after frost & Monti et al. (2008) \\
\hline $\begin{array}{l}\text { Perennial mean } \\
\pm \mathrm{SD}\end{array}$ & $7.5 \pm 4.5$ & $0.73 \pm 0.5$ & $3.9 \pm 2.4$ & & \\
\hline
\end{tabular}


Nutrient removal was reduced by delaying harvest until spring, which dropped $\mathrm{P}$ and $\mathrm{K}$ concentration to $0.08 \mathrm{~kg} \mathrm{P} \mathrm{Mg}^{-1}$ and $0.60 \mathrm{~kg} \mathrm{~K} \mathrm{Mg}^{-1}$. The portion of the plant harvested also impacts nutrient removal rates. For example, harvesting essentially all corn stover with cobs removed $42 \mathrm{~kg} \mathrm{~N}$ $\mathrm{ha}^{-1}$, while harvesting the bottom $50 \%$ (by height) of the plant removed only $13.8 \mathrm{~kg} \mathrm{~N}$ $\mathrm{ha}^{-1}$ (Hoskinson et al., 2007). Harvesting the whole plant removed $34.3 \mathrm{~kg} \mathrm{~K} \mathrm{ha}^{-1}$ and 4.0 $\mathrm{kg} \mathrm{P} \mathrm{ha-1}$, while harvesting only the bottom $50 \%$ removed $33.5 \mathrm{~kg} \mathrm{~K} \mathrm{ha}^{-1}$ and $1.0 \mathrm{~kg} \mathrm{P}$ ha $^{-1}$ (Hoskinson et al., 2007). However, harvest of only the bottom $50 \%$ removed less $\mathrm{N}, \mathrm{P}$, and $\mathrm{K}$ because this portion has only about one-third the amount of dry matter and about twice the water relative to the top $50 \%$, which included the ear shank and cob. Harvesting only cobs would remove 3 to $10 \mathrm{~kg} \mathrm{~N} \mathrm{ha}^{-1}$ (Table 24l3).

Harvesting cellulosic feedstock removes plant nutrients and has the potential to reduce soil fertility (Apland et al., 1981; Smil, 1999; Lal, 2008). It is straightforward to determine nutrient removal from plant concentration and harvest rate, but more difficult to predict subsequent impacts on nutrient cycling and availability. Furthermore, response can vary by nutrient. For example, harvesting stover reduced plant available $\mathrm{K}$ and $\mathrm{Mg}$ after $32 \mathrm{yr}$, but did not significantly reduce other macro- $(\mathrm{N}, \mathrm{P}, \mathrm{Ca})$ or micronutrient (Mn, Zn, Fe) concentrations in soil (Moebius-Clune et al., 2008). Removal of rice and barley (Hordeum vulgare L.) residues reduced both ammonification and nitrification (Kushwaha et al., 2000). Similarly, harvesting corn stover reduced potentially mineralizable N (Kapkiyai et al., 1999; Salinas-Garcia et al., 2001). In contrast, retaining stover in a no-tillage system reduced available $\mathrm{N}$, presumably due to a reduction in soil temperature (Andraski and Bundy, 2008). The highest concentration of soil $\mathrm{P}$ and $\mathrm{K}$ were reported with $100 \%$ stover harvest and $0 \%$ harvest compared with partial harvest for no-tillage corn in Mexico (Roldan et al., 2003).

Inorganic or organic amendments can be used to balance nutrient removal and soil fertility. Traditional amendments such as inorganic fertilizer (Apland et al., 1981; Smil, 1999), animal manures, and composts (Kapkiyai et al., 1999), or unconventional amendments, such as pyrolysis char, gasification ash, or other energy-processing residues (Reijnders, 2006) can be applied to replace removed nutrients and improve soil fertility. For example, in a Kenyan study, application of only dry manure (10 $\mathrm{Mg} \mathrm{ha}^{-1}$ ) improved yield compared with applying comparable amount of inorganic N and P (Kapkiyai et al., 1999). In this same study, yield also was increased when manure was applied in addition to the inorganic P. Inclusion of legumes in a no-tillage system with $66 \%$ stover removal increased the activity of nutrient cycling microbial enzymes (Roldan et al., 2003). Legume intercropping with reed Canary grass (Phalaris arundinacea L.) and awnless brome (Bromus inermis Leyss.) effectively maintained yield in the absence of $\mathrm{N}$ fertilizer (Jasinskas et al., 2008).

\section{Nutrient Management in Perennial Systems}

Perennial systems annually translocate and cycle many plant nutrients; thus they require different nutrient management compared with annual crop species. Fertilizer recommendations likely differ between establishment year and subsequent years. For example, application of $\mathrm{N}$ fertilizer is not recommended during the establishment year of warm-season grasses, to reduce weed competition (Duffy and Nanhou, 2001; Nyoka, 2007). Perennial grasses may have a high affinity for $\mathrm{N}$ recovery, which is why they have been used in grass filter strips to reduce environmental contamination (Bransby et al., 1998). A typical characteristic of perennial grasses is to utilize and even scavenge $\mathrm{N}$, thus it is anticipated perennial grasses will respond to $\mathrm{N}$ fertilization.

Switchgrass yield increased in response to $\mathrm{N}$ fertilizer applied up to $225 \mathrm{~kg} \mathrm{~N} \mathrm{ha}^{-1}$ (Vogel et al., 2002; Heaton et al., 2004; Lemus et al., 2008). Recommended annual $\mathrm{N}$ application rates range from 50 to $224 \mathrm{~kg}$ $\mathrm{ha}^{-1}$ (McLaughlin and Adams Kszos, 2005; Nyoka, 2007; Khanna et al., 2008; Lemus et al., 2008). Switchgrass yields of 10.5 to 12.6 $\mathrm{Mg} \mathrm{ha}^{-1}$ required $120 \mathrm{~kg} \mathrm{~N}^{-1}$ to replace $\mathrm{N}$ removed during harvest, when harvested at peak biomass (Vogel et al., 2002). Comparably, switchgrass required 50 to $140 \mathrm{~kg} \mathrm{~N}$ $\mathrm{ha}^{-1}$, up to $36 \mathrm{~kg} \mathrm{P} \mathrm{ha}^{-1}$, and up to $105 \mathrm{~kg} \mathrm{~K}$ $\mathrm{ha}^{-1}$ to maintain yields from 9 to $15 \mathrm{Mg} \mathrm{ha}^{-1}$ 
(Khanna et al., 2008). Delaying biomass harvest reduced both $\mathrm{N}$ concentration (Table 24I3) and amount of biomass removed, which may translate into lower $\mathrm{N}$ inputs required (Vogel et al., 2002). Improved fertilizer recommendations for switchgrass are still needed to account for regional and cultivar variability (Sanderson et al., 1996; Cassida et al., 2005b; Parrish and Fike, 2005).

Limited information is available on nutrient management for other perennial grasses. Miscanthus produced average yields of $22 \mathrm{Mg} \mathrm{ha}^{-1}$ compared with $10 \mathrm{Mg} \mathrm{ha}^{-1}$ for switchgrass in several studies compared by Heaton et al. (2004). Nitrogen use efficiency decreased but biomass yield increased with $\mathrm{N}$ application for Kentucky bluegrass, smooth bromegrass (Bromus inermis Leyss.), and orchard grass (Dactylis glomerata L.) (Zemenchik and Albrecht, 2002). Seed yield of meadow bromegrass (Bromus riparius Rehmann) increased with fertilizer application (50 or $100 \mathrm{~kg} \mathrm{~N} \mathrm{ha}^{-1}$ ), and harvesting the straw stimulated seed at both fertilizer rates (Loeppky and Coulman, 2002). Mulkey et al. (2008) reported a positive $\mathrm{N}$ response for switchgrass, big bluestem (Andropogon gerardii Vitman) and Indian grass [Sorghastrum nutans (L.) Nash]. In this mixed stand, big bluestem outcompeted switchgrass, and Indian grass virtually disappeared from the stand within 3 yr regardless of $\mathrm{N}$ treatment, demonstrating that stand composition can change over time.

\section{Water Management}

Water quantity and quality issues related to bioenergy production relate both to growing bioenergy feedstock and feedstock conversion. Water requirements vary among conversion platforms, with very little water needed for using biomass as a substitute for natural gas or coal compared with fermentation. It takes about $3 \mathrm{~L}$ of water to produce $1 \mathrm{~L}$ of ethanol by fermentation from grain (Owens, 2007) and 1.9 to $6 \mathrm{~L}$ water to produce $1 \mathrm{~L}$ of ethanol by cellulosic fermentation (Aden, 2007). Assuming a conservative water use efficiency of $10 \mathrm{~kg} \mathrm{ha}^{-1}$ $\mathrm{mm}^{-1}$ (Hatfield et al., 2001), it takes about 14 million $\mathrm{L} \mathrm{ha}^{-1}$ to grow corn yielding $14 \mathrm{Mg}$ $\mathrm{ha}^{-1}$. To convert the $14 \mathrm{Mg} \mathrm{ha}^{-1}$ corn grain into $5500 \mathrm{~L}$ ethanol it takes about 16,500 $\mathrm{L} \mathrm{ha}{ }^{-1}$ water using a corn grain ethanol conversion rate of $0.396 \mathrm{~L} \mathrm{~kg}^{-1}$ (Shapouri et al., 2003). Clearly, more water is needed to raise corn compared with the amount of water needed to operate an ethanol fermentation plant. In regions where water supplies are limited, nonagricultural (e.g., human consumption, wildlife, recreation) water demands compete with water available for irrigation (Postel and Richter, 2003). A vigorous, factual, public discussion and debate of the pros and cons of using water to irrigate biofuel feedstock is appropriate for policy development, but beyond the scope of this discussion.

Evapotranspiration dynamics differ among species and can be altered by management (Hatfield et al., 2001), and will occur regardless if the crop was raised for grain or for grain and residue. However, more water is lost from the soil when crop residues are removed (Al-Darby et al., 1989), which is especially important in semiarid or arid lands. Residues increase infiltration and decrease evaporation, generally resulting in a net increase in soil moisture (Smika and Unger, 1986; Blevins and Frye, 1993; Wells et al., 2003; Govaerts et al., 2007). Therefore, additional water inputs may be needed when residues in addition to grain are harvested.

In general, water holding capacity is increased with increasing SOM (Hudson, 1994); therefore, if biomass harvest causes a reduction in SOM, water holding capacity could also be reduced. Maintaining soil cover tends to increase water use efficiency by (i) reducing the potential for soil crusting and erosion, (ii) improving water infiltration, and (iii) reducing evaporation (Aase and Pikul, 1995). Changes at the soil surface due to residue management can have hydrological impacts. For example, Tomer et al. (2005) reported incorporation of residue increased the overland flow component of stream discharge from small watersheds by nearly $50 \%$ in a 25-yr study. Alas, research data on the impact of widespread biomass feedstock harvest on watershed hydrology is lacking (Uhlenbrook, 2007).

Intensive agriculture has been identified as a significant source of nutrients and pesticides in surface and groundwater. Concerns have been raised about biomass feedstock production exacerbating pollution of surface and groundwater resources (Nyakatawa et al., 2006; Simpson et al., 
2008). Conversion of perennial systems into row crops presents a much greater environmental risk than converting row crops into perennial biomass systems (Nelson et al., 2006). Compensating measures such as including cover crops are recommended when crop straws are harvested (Dabney et al., 2001). However, in arid or semiarid regions water use by cover crops may be detrimental (Unger and Vigil, 1998) so other measures would be needed. Eliminating tillage can reduce pesticide leaching (Gish et al., 1998) and nitrate leaching (Mkhabela et al., 2008). Managing the water table through subsurface irrigation and drainage such that water and nitrates are kept in the soil profile is a strategy to reduce nitrate loading in surface- and groundwater (Elmi et al., 2004). Expansion or addition of riparian buffer strips alongside biomass harvest area would reduce surface runoff reaching waterways (Bharati et al., 2002). Water quality must be safeguarded through improved water management whereby nutrient and pesticide loading to surface and groundwater is reduced and ideally eliminated.

\section{Harvest Strategies}

Strategies will vary by the biomass feedstock (e.g., cobs, stover, straw, and perennial grasses) harvested. Baling small grain straw is a well-established

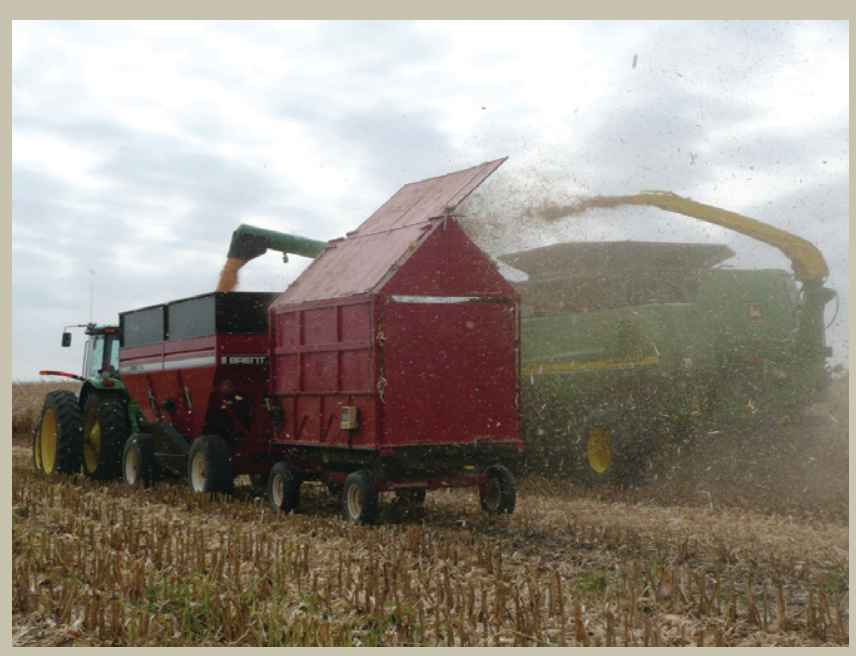

Fig. 24|3. Corn grain and stover being collected using a one-pass harvesting system near Ames, IA. practice, historically associated with animal husbandry. Thus, for many producers, utilizing the straw as a biomass feedstock would not require learning additional skills or acquiring additional equipment. Small grain is harvested earlier in the season, when there may be more time available for the producer to harvest the straw. Until a one-pass harvest system is commercially available, corn stover or small grain straw requires additional harvest operations such as baling (Petrolia, 2008). Completing corn harvest in a timely manner is an especially important driving force behind developing corn harvest equipment that can remove and separate grain and biomass feedstock (cobs or stover) in one pass (Fig. 24/3) (Hoskinson et al., 2007). A one-pass harvest system reduces soil contamination of feedstock, improves harvest timeliness, and reduces costs.

\section{Stover Harvest}

Hoskinson et al. (2007) used a prototype one-pass system to evaluate four different harvesting scenarios for corn grain and biomass components in both a continuous corn and corn-soybean rotation in Iowa. The four biomass harvest scenarios were (i) the top $50 \%$ of the plant by height, (ii) the bottom $50 \%$ of the plant, (iii) all harvestable stover, or (iv) no stover. Corn grain and stover were harvested in 2005, 2006, and 2007 at the continuous corn site, but only in 2005 and 2007 at the rotated site (Table 24/4). Information was collected on feedstock quantity for each of the four harvest treatments. These data were compared with guidelines developed by Wilhelm et al. (2007) (Fig. $24 / 2)$ to determine the potential impact on SOC levels. Harvesting all recoverable aboveground stover (whole plant treatment) from continuous corn exceeded the recommended harvest rates by $3.50,5.87$, and 3.17 $\mathrm{Mg} \mathrm{ha}{ }^{-1}$ in 2005, 2006, and 2007, respectively. All four 
Table 24|4. Corn grain (15.5\% moisture) and dry stover yield from continuous and rotated sites near Ames, IA. Both sites were managed using fall chisel plowing and field cultivation in the spring to prepare the seedbed each year.

\begin{tabular}{|c|c|c|c|c|c|c|}
\hline \multirow[t]{3}{*}{ Stover fraction } & 2005 & 2006 & 2007 & 2005 & 2006 & 2007 \\
\hline & \multicolumn{6}{|c|}{ Continuous corn } \\
\hline & \multicolumn{3}{|c|}{$\longrightarrow$ Mg grain ha ${ }^{-1}$} & \multicolumn{3}{|c|}{ - Mg stover ha ${ }^{-1}$} \\
\hline Whole plant & 10.41 & 9.41 & 12.04 & 4.71 & 6.14 & 5.61 \\
\hline Cob and top $50 \%$ & 10.35 & 9.53 & 12.04 & 2.91 & 4.98 & 4.42 \\
\hline Bottom 50\% & 10.35 & 9.22 & 11.85 & 1.26 & 1.48 & 0.70 \\
\hline Grain only & 10.41 & 8.97 & 11.41 & - & - & - \\
\hline \multirow[t]{2}{*}{ Annual avg./avg. total stover $†$} & 10.38 & 9.28 & 11.84 & 8.77 & 7.84 & 10.0 \\
\hline & \multicolumn{6}{|c|}{ Corn-soybean rotation } \\
\hline Whole plant & 12.73 & - & 13.17 & 7.11 & - & 5.67 \\
\hline Cob and top 50\% & 12.35 & - & 12.86 & 4.62 & - & 4.93 \\
\hline Bottom 50\% & 11.66 & - & 13.29 & 1.48 & - & 1.55 \\
\hline Grain only & 12.42 & - & 12.98 & - & - & - \\
\hline Annual avg/avg. total stover & 12.29 & & 13.08 & 10.39 & & 11.05 \\
\hline
\end{tabular}

† Assuming a 1:1 dry grain to dry stover ratio, this is amount of biomass produced.

removal treatments used at the rotated site exceeded the guideline of $12.50 \mathrm{Mg}$ $\mathrm{ha}^{-1}$ of stover necessary to sustain SOM and the $8 \mathrm{Mg} \mathrm{ha}^{-1}$ necessary for water erosion control. Therefore, no removal of biomass would be recommended, which was confirmed by the rill erosion occurring after an extremely intense rainfall event in spring 2008 (Fig. 24|1).

An alternative to annually limiting biomass harvest based on annual SOC guidelines (Wilhelm et al., 2007) would be to rotate harvest in time, such that on average the SOC guidelines are met. For example, assume two years of continuous corn, yielding $10 \mathrm{Mg}$ dry stover ha- $\mathrm{yr}^{-1}$. If during year one $7 \mathrm{Mg} \mathrm{ha}^{-1}$ were harvested and $3 \mathrm{Mg} \mathrm{ha}^{-1}$ left in the field and during year two no stover were harvested, then $13 \mathrm{Mg} \mathrm{ha}^{-1}$ stover or an average of $6.5 \mathrm{Mg}$ $\mathrm{ha}^{-1} \mathrm{yr}^{-1}$ would be returned. Therefore, in continuous corn, alternating stover harvest would provide on average enough C inputs as well as sufficient ground cover to maintain SOC and prevent erosion (Fig. 24/2). Stover should be harvested less often, perhaps only once every $3 \mathrm{yr}$, if more aggressive tillage is used, or every other corn year in a corn-soybean rotation. From a manager's perspective, especially in the absence of commercially available harvest equipment, it may be more desirable to rotate harvest in time rather than trying to harvest only a small percent of a given standing crop.

\section{Cob Harvest}

The low density of corn stover and other herbaceous material presents major transportation and handling challenges (Perlack and Turhollow, 2002). Furthermore, excessive stover harvest from any area within a field could adversely affect water entry, retention, runoff, nutrient cycling, productivity, and many other critical soil functions (Wilhelm et al., 2007). Therefore, the ethanol industry is exploring the feasibility of using corn cobs as a biofuel feedstock (e.g., http:// www.poet.com/innovation/cellulosic/ and http://www.cvec.com/ [verified 16 Sept. 2010]). Corn cobs have several advantages compared with using all of the stover for either thermochemical or biochemical (fermentation) conversion platforms. Crofcheck and Montross (2004) found that cobs had higher glucose concentration during enzyme hydrolysis than other stover fractions with and without pretreatment. This suggests corn cobs could have very high quality as a cellulosic fermentation feedstock. Total energy content of corn stover fractions (cobs, husk, leaves, stalks, and grain) ranged from 16.7 to $20.9 \mathrm{~kJ} \mathrm{~g}^{-1}$ at physiological maturity, with cobs being at 
the higher end of this range (Pordesimo et al., 2005). Others (Treier et al., 2006; Yu et al., 2008) reported similar heat values (18.4-18.7 $\mathrm{kJ} \mathrm{g}^{-1}$ ) with low ash, $\mathrm{N}$, and $\mathrm{S}$ relative to coal. Low $\mathrm{N}$ and $\mathrm{S}$ concentrations also reduce the potential production of $\mathrm{NOx}$ and $\mathrm{SO}_{2}$ pollutants. Harvesting only the corn cobs also helps address the biomass density issue because of their relatively uniform size and shape that exists after coarse grinding. Collection of only cobs would also leave most of the corn stover in the field (Pordesimo et al., 2004), which has multiple benefits with regard to minimizing soil erosion (Lindstrom, 1986; Erenstein, 2002) by protecting the soil from erosive forces (Wilson et al., 2004) and sustaining soil carbon (Johnson et al., 2006a; Wilhelm et al., 2007). A multistate survey conducted by the USDA-Agricultural Resource Service, Renewable Energy Assessment Project (REAP) team found that on a weight basis, cobs accounted for 15 to $20 \%$ of the aboveground nongrain biomass under a wide variety of conditions (Wilhelm et al., 2010). This range is consistent with data for irrigated corn in Colorado and Texas (Halvorson and Johnson, 2009) and in the western Corn Belt (Varvel and Wilhelm, 2008b). Cobs have potential for feedstock, especially if only limited stover is available for harvest after meeting SOC and soil coverage needs.

\section{Other Feedstock Harvest}

In the Corn Belt, corn cob and stover are likely primary feedstocks, but in other regions, the primary feedstock may be small grain straw (Banowetz et al., 2008), perennial grasses (McLaughlin and Adams Kszos, 2005), or wood products. Integrating use of primary with secondary feedstocks could increase temporal and spatial diversity within the landscape. Multiple feedstocks may encourage growing more perennial species, including prairie mixtures.

Feedstocks with temporally diverse harvest windows are desirable from a time management standpoint. Multiple feedstocks with staggered harvest dates may reduce storage capacity needs, but must fit within the existing management. For example, harvesting perennial grasses after a killing frost may interfere with harvesting corn and soybean, due to labor constraints. Harvesting perennial grasses in very early spring before nesting would provide winter cover for wildlife, but in northern regions (e.g., Minnesota) late snows can delay or prevent spring harvest (Fig. 24|4). Managing harvest of perennial grasses will also require understanding the potential tradeoff in harvest timing between maximizing biomass yield versus timing harvest to minimize nutrient removal and maintaining stand integrity (Vogel et al., 2002; Mulkey et al., 2006; Lee et al., 2007).

As the bioeconomy develops, efficient, timely, and commercially available harvest systems will evolve. The amount of biomass that is needed on the land to control erosion and maintain SOC are considerations for determining what is harvested, how and when biomass is harvested, and how frequently. Expanding crop rotations, incorporating cover crops, reducing tillage, and rotating harvest in time are all strategies that can be used to sustain soil while sustaining economic viability of biofuel feedstock.
Fig. 24|4. Standing switchgrass in western Minnesota with early April snow accumulated, delaying spring harvest. 


\section{Economic Drivers}

Biomass prices can have a critical impact on how crops are managed. In order for biomass harvest to be economically feasible, biomass prices must offset any additional costs incurred. Additional costs may include biomass harvest, storage, and transportation; nutrient replacement; impacts on current and future crop productivity; and implementing changes in production practices to facilitate biomass production (e.g., changes in tillage or rotation). As biomass prices increase relative to other crops, there are increased economic incentives for greater biomass removal. This includes incentives to harvest biomass on more acreage and incentives to increase production per unit land area.

Collection costs per unit of biomass tend to decline at higher removal rates and higher yields (Duffy and Nanhou, 2002; Graham et al., 2007). This provides an economic incentive for a farmer to harvest the highest yielding biomass crops at the highest practical rates, increasing production per unit land area. With annual crop residues, this might be somewhat tempered by high water content of stover, nutrient replacement requirements at higher removal rates, and the degree to which biomass harvest activities interfere with grain harvest (Hoskinson et al., 2007). However, the importance of these effects depends on the harvest technology used. For example, high moisture content of the stover is not an important issue when wet harvest and storage is used instead of dry harvest and storage (Shinners et al., 2007). The importance of these effects also depends on the biomass price. Higher biomass prices increase the value of biomass production, so that it may be profitable to incur additional production costs, including paying higher nutrient replacement costs and making expenditures or production changes to reduce interference with grain harvest activities (Apland et al., 1981; Bender et al., 1984).

Biomass harvest removes plant nutrients (Table 24l3), and replacing these nutrients can represent a significant production expense. For whole stover removal, the replacement cost of both macro- and micronutrients was estimated as high as $\$ 118 \mathrm{ha}^{-1}$ beyond the cost of producing grain (Table 2415). Input costs of fertilizers vary among production systems. For instance, total operating costs over $20 \mathrm{yr}$ were substantially higher for miscanthus production in Illinois than for switchgrass, $\$ 11,748 \mathrm{ha}^{-1}$ compared

Table 24|5. Average nutrient removal for five site-years and 2008 replacement cost for various fractions of corn stover harvested as a potential biofuel feedstock near Ames, IA (Karlen et al., unpublished data).

\begin{tabular}{|c|c|c|c|c|c|c|}
\hline \multirow[t]{2}{*}{ Stover fraction } & \multicolumn{2}{|l|}{$\mathrm{N}$} & \multicolumn{2}{|l|}{$\mathrm{P}$} & \multicolumn{2}{|l|}{$\mathrm{K}$} \\
\hline & $\mathrm{kg} \mathrm{ha}^{-1}$ & $\$$ ha $^{-1} \dagger$ & $\mathrm{kg} \mathrm{ha}^{-1}$ & $\$$ ha $^{-1}$ & $\mathrm{~kg} \mathrm{ha}^{-1}$ & $\$ h^{-1}$ \\
\hline Whole plant & 39 & 47.93 & 3.2 & 22.20 & 34 & 37.67 \\
\hline Cob and top 50\% & 29 & 35.64 & 3.1 & 21.50 & 28 & 31.02 \\
\hline \multirow[t]{3}{*}{ Bottom 50\% } & 7 & 8.60 & 0.7 & 4.86 & 9 & 9.97 \\
\hline & \multicolumn{2}{|l|}{$\mathrm{Ca}$} & \multicolumn{2}{|l|}{$\mathrm{Mg}$} & \multicolumn{2}{|l|}{$\mathrm{Cu}$} \\
\hline & $\mathrm{kg} \mathrm{ha}^{-1}$ & $\$$ ha $^{-1}$ & $\mathrm{~kg} \mathrm{ha}^{-1}$ & $\$$ ha $^{-1}$ & $\mathrm{~g} \mathrm{ha}^{-1}$ & $\$ \mathrm{ha}^{-1}$ \\
\hline Whole plant & 23 & 1.55 & 17 & 3.17 & 20 & 0.46 \\
\hline Cob and top $50 \%$ & 14 & 0.94 & 10 & 1.87 & 20 & 0.46 \\
\hline \multirow[t]{3}{*}{ Bottom 50\% } & 6 & 0.40 & 5 & 0.93 & 2 & 0.05 \\
\hline & \multicolumn{2}{|l|}{$\mathrm{Fe}$} & \multicolumn{2}{|l|}{$\mathrm{Mn}$} & \multicolumn{2}{|l|}{$\mathrm{Zn}$} \\
\hline & $\mathrm{g} \mathrm{ha}^{-1}$ & $\$$ ha $^{-1}$ & $\mathrm{~g} \mathrm{ha}^{-1}$ & $\$$ ha $^{-1}$ & $\mathrm{~g} \mathrm{ha}^{-1}$ & $\$ \mathrm{ha}^{-1}$ \\
\hline Whole plant & 523 & 2.93 & 128 & 0.92 & 88 & 0.77 \\
\hline Cob and top 50\% & 299 & 1.67 & 69 & 0.50 & 69 & 0.61 \\
\hline Bottom 50\% & 162 & 0.91 & 29 & 0.21 & 17 & 0.15 \\
\hline
\end{tabular}

† Prices based on cost to growers on 23 July 2008: N, \$1.229 kg-1; P, \$6.936 kg-1; K, \$1.108 kg-1; Ca, \$0.0672 kg-1; Mg, $\$ 0.1867 \mathrm{~kg}^{-1}$; Cu, $\$ 0.0229 \mathrm{~kg}^{-1}$; Fe, $\$ 0.0056 \mathrm{~g} \mathrm{~g}^{-1}$; Mn, $\$ 0.0072 \mathrm{~g}^{-1} ; \mathrm{Zn}, \$ 0.0088 \mathrm{~g} \mathrm{~g}^{-1}$. N-P-K were calculated for using anhydrous ammonia for $\mathrm{N}$, diammonium phosphate for $\mathrm{P}_{2} \mathrm{O}_{5}$, and muriate $(\mathrm{KCl})$ for $\mathrm{K}$; Ca was based on calcitic limestone $40 \%$ $\mathrm{Ca}$; Mg was based on dolomitic limestone 9\% Mg; Cu as copper sulfate; Fe as iron sulfate; Mn as Manganese oxide; and $\mathrm{Zn}$ as zinc oxide. 
with $\$ 2775 \mathrm{ha}^{-1}$ at the farm gate, with $\$ 571$ $\mathrm{ha}^{-1}$ and $\$ 484 \mathrm{ha}^{-1}$ for $\mathrm{N}, \mathrm{P}, \mathrm{K}$, and lime, respectively (Khanna et al., 2008). Replacement costs of $P$ and $K$ for switchgrass grown in Iowa were estimated at $\$ 7.78$ and $\$ 47.32$ ha $^{-1}$ (Duffy and Nanhou, 2001), which would be considerably higher using 2008 dollars. One promising aspect of energy production would be to recover $\mathrm{N}$ before gasification in a coupled gasification and ethanol production process (Anex et al., 2007). Potentially 28 to $78 \%$ of the $\mathrm{N}$ fertilizer applied in corn stover and switchgrass biomass systems could be recovered by this process. Once recovered, the nutrients could be transported back to the farm.

Feedstock removal rates are limited by the need to leave sufficient nongrain biomass on the land to control soil erosion and to maintain soil quality (Johnson et al., 2006a; Johnson et al., 2006b; Wilhelm et al., 2007). While these limits might be imposed by regulation, producers recognize the economic incentives to limit removal rates. Excessive biomass removal can lead to increased soil erosion and reductions in SOC, which have environmental consequences as well as impacts on future crop productivity (Wilhelm et al., 2004). If producers perceive negative impacts on crop productivity, this provides an incentive against excessive removal. While increasing biomass price produces a short-term incentive to increase biomass harvest, it also produces an incentive to maintain future productivity. At some point, it may become profitable to change management in ways that allow for a higher harvest level. Several analyses of potential biomass supply assumed that producers would switch to less-intensive tillage systems to increase the amount of crop residues that could be harvested (Gallagher et al., 2003; Sheehan et al., 2004; Perlack et al., 2005; Graham et al., 2007). Other potential production changes include the use of cover crops (Anex et al., 2007) and changes in crop varieties or crop rotations to increase crop residue cover or biomass production, or to make biomass harvest more timely. Potential examples include changing from a corn-soybean to a continuous corn rotation to increase average biomass production (Sheehan et al., 2004), inclusion of perennial biomass crops in annual cropping systems (Anex et al., 2007), long-term conversion from annual crops to perennial crops (Varvel et al., 2008), or inclusion of wheat in rotation with corn to allow early fall straw harvest instead of late fall corn stover harvest (Apland et al., 1981). Policy analyses helped identify the production shifts that might occur across broad areas and a limited set of production alternatives (De La Torre Ugarte et al., 2003; Schneider and McCarl, 2003). However, the relevant price levels and resulting production shifts are likely to be producer and site specific. Producers may be able to harvest biomass feedstock (such as corn stover or wheat straw) with only minor changes to their production systems, while incorporating dedicated biomass crops (perennial woody or herbaceous) could require additional equipment and facilities. Substantial management changes and associated costs with perennial species feedstocks are compounded by multiple-year commitments and a delay from planting to first harvest, dramatically increasing associated risks. Therefore, larger price incentives or market assurances may be required to stimulate a production shift (Larson et al., 2008).

\section{Integration}

The rapidly emerging soil management technologies being developed to use corn stover and other lignocellulosic materials to produce biofuel and other bioproducts offer an opportunity to increase the net environmental benefits of agriculture by using crop rotations that are more temporally and spatially diverse than current rotations. Implementing diverse rotations, especially rotations that include perennial biomass feedstocks and integrating multiple feedstocks, provides multiple environmental, social, and economic benefits. Using strategies to minimize negative impacts and maximize potential benefits will help avoid many of the concerns raised by Doornbosch and Steenblik (2007), Ernsting and Boswell (2007), Fargione et al. (2008), and Searchinger et al. (2008). These authors raised concerns that putting new lands (e.g., rainforest) into production, especially production of annual species, will release more greenhouse gas than can be offset by using biomass for energy. Their arguments strengthen the case for developing a bioeconomy that includes sustainability 
as an a priori criterion. This would support policy and management decisions that discourage land use change, and encourage the use of practices that protect soil, water, and air resources.

Implementation of more diverse rotations in time and space for producing bioenergy feedstocks and solving many of the current "externalities" associated with agriculture has become more feasible with the advent of global positioning systems (GPS), geographic information systems (GIS), remote sensing, and related technologies for precision-or site-specific-mapping and management of crops. These technologies can be used to manage fertilizer and pesticide inputs (Giles and Slaughter, 1997; Tian et al., 1999; Ferguson et al., 2002; Khosla et al., 2002; Robert, 2002), guide the placement of drainage tile and terraces (Zhang et al., 2002), encourage in-field and field-edge conservation practices (Berry et al., 2003; Dinnes, 2004), and support placement of specific crops, rotations, and tillage practices within individual fields (Kitchen et al., 2005). New technologies can also help optimize water quality across watersheds and ecoregions (Hatch et al., 2001).

\section{Concluding Remarks}

Corn stover and corn cobs represent nearterm herbaceous feedstocks for cellulosic ethanol production and/or thermochemical platforms. As the bioeconomy matures, other feedstocks (cellulosic and oilseed) likely will develop and expand. The feedstock market and production (all-inclusive planting, harvest, transport, and storage) will develop and evolve. Dominant cellulosic feedstock will vary by region and season. Multiple feedstocks with temporally diverse harvest will improve time management and reduce on- or off-farm storage needs. Routine broadscale biomass harvest needs to be managed such that it does not exacerbate soil erosion or loss of SOC. Annual harvest rates should maintain sufficient cover to control erosion; harvestable biomass decreases as tillage intensity increases. In general, more biomass needs to be returned to maintain SOC than to control erosion. Sufficient biomass inputs can be achieved by limiting the amount of biomass harvested, for example harvesting only cobs or the top portion of the corn stalk. Another strategy is to limit the frequency biomass is harvested on a given field. Management practices such as reducing or eliminating tillage, adding cover crops, and including perennials are all means of increasing the amount of harvestable biomass while maintaining SOC and soil quality. These management strategies also help safeguard water quality. Additional management strategies for protecting water quality include managing irrigation and drainage to reduce nutrient loading, and adding or expanding riparian buffers to reduce surface runoff. Furthermore, soil cover can increase water use efficiency by reducing the potential for soil crusting and erosion, improving water infiltration, and by reducing evaporation. Nutrient management will need to be altered to compensate for the additional nutrient removal and adapted for perennial crops. Limiting $\mathrm{N}$ availability during establishment of perennial grasses can reduce weed pressure. Delaying perennial harvest until after senescence or until spring can reduce the amount of nutrients removed in the biomass. Soil fertility should be monitored by soil testing and crops scouted for deficiency symptoms, including micronutrients, so nutrient management can be adjusted as necessary to support biomass harvest. Overall, protecting soil, water, and air resources through improved soil and crop management is essential to developing the bioenergy industry in a manner that ensures long-term environmental and economic sustainability.

\section{Acknowledgments}

This work contributes to the objectives of the USDA-ARS-Renewable Energy Assessment Project (REAP) cross-location project. The authors wish to thank B. Burmeister for careful editing, but take full responsibility for any errors. The authors dedicate this work to Wally Wilhelm for his inspiration and commitment to sustainable bioenergy.

\section{References}

Aase, J.K., and J.L. Pikul, Jr. 1995. Crop and soil response to long-term no tillage practices in the Northern Great Plains. Agron. J. 87:652-656.

Abiven, S., S. Recous, V. Reyes, and R. Oliver. 2005. Mineralisation of $\mathrm{C}$ and $\mathrm{N}$ from root, stem and leaf residues in soil and role of their biochemical quality. Biol. Fertil. Soils 42:119-128. 
Aden, A. 2007. Water use for current and future ethanol production. Southwest Hydrol. 6(5):22-23.

Adler, P.R. M.A. Sanderson, A.A. Boateng, PJ. Weimer, and H.-J.G. Jung. 2006. Biomass yield and biofuel quality of switchgrass harvested in fall or spring. Agron. J. 98:1518-1525.

Al-Darby, A.M., M.A. Mustafa, A.M. Al-Omran, and M.O. Mahjoub. 1989. Effect of wheat residue and evaporative demands on intermittent evaporation. Soil Tillage Res. 15:105-116.

Al-Kaisi, M.M., X. Yin, and M.A. Licht. 2005. Soil carbon and nitrogen changes as affected by tillage system and crop biomass in a corn-soybean rotation. Appl. Soil Ecol. 30:174-191.

Andraski, T.W., and L.G. Bundy. 2008. Corn residue and nitrogen source effects on nitrogen availability in notill corn. Agron. J. 100:1274-1279.

Andren, O., and K. Paustian. 1987. Barley straw decomposition in the field: A comparison of models. Ecology 68:163-210.

Anex, R.P., L.R. Lynd, M.S. Laser, A.H. Heggenstaller, and M. Liebman. 2007. Potential for enhanced nutrient cycling through coupling of agricultural and bioenergy systems. Crop Sci. 47:1327-1335.

Apland, J., B.A. McCarl, and T.G. Baker. 1981. Crop residue supply for energy generation: A prototype application to Midwestern U.S.A. grain farms. Energy Agric. 1:55-70.

Baker, J.M., T.E. Ochsner, R.T. Venterea, and T.J. Griffis 2007. Tillage and soil carbon sequestration-What do we really know? Agric. Ecosyst. Environ. 118:1-5.

Banowetz, G.M., A. Boateng, J.J. Steiner, S.M. Griffith, V. Sethi, and H. El-Nashaar. 2008. Assessment of straw biomass feedstock resources in the Pacific Northwest. Biomass Bioenergy 32:629-634.

Bayer, C., T. Lovato, J. Dieckow, J.A. Zanatta, and J. Mielniczuk. 2006. A method for estimating coefficients of soil organic matter dynamics based on long-term experiments. Soil Tillage Res. 91:217-226.

Bender, D.A., R.M. Peart, D.H. Doster, J.R. Barrett, and M.O. Bagby. 1984. Energy crop evaluation by linear programming. Energy Agric. 3:199-210.

Berry, J.K., J.A. Delgado, R. Khosla, and F.J. Pierce. 2003. Precision conservation for environmental sustainability. J. Soil Water Conserv. 58(6):332-339.

Bharati, L., K.H. Lee, T.M. Isenhart, and R.C. Schultz. 2002. Soil-water infiltration under crops, pasture, and established riparian buffer in Midwestern USA. Agrofor. Syst. 56:249-257.

Bilbro, J.D., and D.W. Fryrear. 1994. Wind erosion losses as related to plant silhouette and soil cover. Agron. J. 86:550-553

Blevins, R.L., and W.W. Frye. 1993. Conservation tillage: An ecological approach to soil management. Adv. Agron. 51:33-78.

Borie, F., Y. Redel, R. Rubio, J.L. Rouanet, and J.M. Barea 2002. Interactions between crop residues application and mycorrhizal developments and some soil-root interface properties and mineral acquisition by plants in an acidic soil. Biol. Fertil. Soils 36:151-160.

Bransby, D.I., S.B. McLaughlin, and D.J. Parrish. 1998. A review of carbon and nitrogen balances in switchgrass grown for energy. Biomass Bioenergy 14:379-384.

Breakwell, D.P., and R.F. Turco. 1989. Nutrient and phytotoxic contributions of residue to soil in notill continuous-corn ecosystems. Biol. Fertil. Soils 8:328-334.

Brigham, R.D. 1993. Castor: Return of an old crop. p. 380 383. In J. Janick and J. E. Simon (ed.) New crops. John Wiley \& Sons, New York.

Bruun, S., B.T. Christensen, E.M. Hansen, J. Magid, and L.S. Jensen. 2003. Calibration and validation of the soil organic matter dynamics of the Daisy model with data from the Askov long-term experiments. Soil Biol. Biochem. 35:67-76.

Burgess, M.S., G.R. Mehuys, and C.A. Madramootoo. 2002. Decomposition of grain-corn residues (Zea mays L.): A litterbag study under three tillage systems. Can. J. Soil Sci. 82:127-138.

Carlson, K.D., J.C. Gardner, V.L. Anderson, and J.J. Hanzel. 1996. Crambe: New crop success. p. 306-322. In J. Janick (ed.) Progress in new crops. ASHS Press, Alexandria, VA.

Cassida, K.A., J.P. Muir, M.A. Hussey, J.C. Read, B.C. Venuto, and W.R. Ocumpaugh. 2005a. Biofuel component concentrations and yields of switchgrass in south central U.S. environments. Crop Sci. 45:682-692.

Cassida, K.A. J.P. Muir, M.A. Hussey, J.C. Read, B.C. Venuto, and W.R. Ocumpaugh. 2005b. Biomass yield and stand characteristics of switchgrass in south central U.S. environments. Crop Sci. 45:673-681.

Christensen, B.T. 1986. Barley straw decomposition under field conditions: Effects of placement and initial nitrogen content on weight loss and nitrogen dynamics. Soil Biol. Biochem. 18:523-529.

Clifton-Brown, J.C., and I. Lewandowski. 2002. Screening Miscanthus genotypes in field trials to optimise biomass yield and quality in Southern Germany. Eur. J. Agron. 16:97-110.

Cookson, W.R., M.H. Beare, and P.E. Wilson. 1998. Effects of prior crop residue management on microbial properties and crop residue decomposition. Appl. Soil Ecol. 7:179-188.

Cox, C.A. 2008. Beyond T: Guiding sustainable soil management. J. Soil Water Conserv. 63(5):162A-164A.

Crofcheck, C.L., and M.D. Montross. 2004. Effect of stover fraction on glucose production using enzymatic hydrolysis. Trans. ASABE 47:841-844.

CTIC. 2002. National Crop Residue Management Survey. Available at http://www.ctic.purdue.edu/CRM/ (posted 2002; verified 6 Oct. 2010). Conserv. Technol. Inf. Cent., West Lafayette, IN.

Dabney, S.M., J.A. Delgado, and D.W. Reeves. 2001. Using winter cover crops to improve soil and water quality. Commun. Soil Sci. Plant Anal. 32:1221-1250.

De La Torre Ugarte, D.G., M.E. Walsh, H. Shapouri, and S.P. Slinsky. 2003. The economic impacts of bioenergy crop production on U.S. agriculture. Agric. Econ. Rep. No. 816. USDA-ERS, Washington, DC.

Demirbas, A. 2006. Biodiesel production via non-catalytic SCF method and biodiesel fuel characteristics. Energy Convers. Manage. 47:2271-2282.

Dexter, A.R., D. Hein, and J.S. Hewett. 1982. Macro-structure of the surface layer of self-mulching clay in relation to cereal stubble management. Soil Tillage Res. 2:251-264.

Dierig, D.A., T.A. Coffelt, F.S. Nakayama, and A.E. Thompson. 1996. Lesquerell and vernonia: Oilseeds for arid lands. p. 347-354. In J. Janick (ed.) Progress in new crops. ASHS Press, Alexandria, VA.

Dinnes, D.L. 2004. Assessments of practices to reduce nitrogen and phosphorus nonpoint source pollution of Iowa's surface waters. Available at http://www. iowadnr.gov/water/nutrients/files/nps_assessments. pdf (verified 16 Sept. 2010). Iowa Dep. of Nat. Resour., Des Moines, IA and USDA-ARS Natl. Soil Tilth Lab., Ames, IA.

Doornbosch, R., and R. Steenblik. 2007. Biofuels: Is the cure worse than the disease? SG/SD/RT(2007)3. OECD, Paris.

Duffy, M.D., and V.Y. Nanhou. 2001. Costs of producing switchgrass for biomass in Iowa. PM 1866. Available at http://www.extension.iastate.edu/Publications/ PM1866.pdf (posted April 2001; verified 16 Sept. 2010) Iowa State Univ. Ext., Ames.

Duffy, M.D., and V.Y. Nanhou. 2002. Costs of producing switchgrass for biomass in Southern Iowa. p. 267-275. 
In J. Janick and A. Whipkey (ed.) Trends in new crops and new uses. ASHS Press, Alexandria, VA.

Elmi, A.A., C. Madramootoo, M. Egeh, and C. Hamel. 2004. Water and fertilizer nitrogen management to minimize nitrate pollution from a cropped soil in southwestern Quebec, Canada. Water Air Soil Pollut. 151:117-134.

Erenstein, O. 2002. Crop residue mulching in tropical and semi-tropical countries: An evaluation of residue availability and other technological implications. Soil Tillage Res. 67:115-133.

Ernsting, A., and A. Boswell. 2007. Agrofuels: Towards a reality check in nine key areas. Available at http:// www.corporateeurope.org/docs/AgrofuelsRealityCheck.pdf (verified 16 Sept. 2010). Biofuelwatch.

Fageria, N.K. 2004. Dry matter yield and shoot nutrient concentrations of upland rice, common bean, corn, and soybean grown in rotation on an Oxisol. Commun. Soil Sci. Plant Anal. 35:961-974.

Fargione, J., J. Hill, D. Tilman, S. Polasky, and P. Hawthorne. 2008. Land clearing and the biofuel carbon debt. Science 319:1235-1238.

Fatondji, D., C. Martius, C. Bielders, P. Vlek, A. Bationo, and B. Gerard. 2006. Effect of planting technique and amendment type on pearl millet yield, nutrient uptake, and water use on degraded land in Niger. Nutr. Cycling Agroecosyst. 76:203-217.

Ferguson, R.B., G.W. Hergert, J.S. Schepers, C.A. Gotway, J.E. Cahoon, and T.A. Peterson. 2002. Site-specific nitrogen management of irrigated maize: Yield and soil residual nitrate effects. Soil Sci. Soc. Am. J. 66:544-553.

Frank, A.B., J.D. Berdahl, J.D. Hanson, M.A. Liebig, and H.A. Johnson. 2004. Biomass and carbon partitioning in switchgrass. Crop Sci. 44:1391-1396.

Franzluebbers, A.J., F.M. Hons, and V.A. Saladino. 1995 Sorghum, wheat and soybean production as affected by long-term tillage, crop sequence and $\mathrm{N}$ fertilization. Plant Soil 173:55-65.

Gallagher, P.W., M. Dikeman, J. Fritz, E. Wailes, W. Gauthier, and H. Shapouri. 2003. Supply and social cost estimates for biomass from crop residues in the United States. Environ. Resour. Econ. 24:335-358.

Gesch, R.W., F. Forcella, A.E. Olness, D.W. Archer, and A. Hebard. 2006. Agricultural management of cuphea and potential for commercial production in the United States. Ind. Crops Prod. 24:300-306.

Giles, D.K., and D.C. Slaughter. 1997. Precision band sprayer with machine-vision guidance and adjustable yaw nozzles. Trans. ASAE 40(1):29-36.

Gish, T.J., D. Gimenez, and W.J. Rawls. 1998. Impact of roots on ground water quality. Plant Soil 200:47-54.

Goodrum, J.W., and D.P. Geller. 2005. Influence of fatty acid methyl esters from hydroxylated vegetable oils on diesel fuel lubricity. Bioresour. Technol. 96:851-855.

Govaerts, B., M. Fuentes, M. Mezzalama, J.M. Nicol, J. Deckers, J.D. Etchevers, B. Figueroa-Sandoval, and K.D. Sayre. 2007. Infiltration, soil moisture, root rot and nematode populations after 12 years of different tillage, residue and crop rotation managements. Soil Tillage Res. 94:209-219.

Graham, R.L., R. Nelson, J. Sheehan, R.D. Perlack, and L.L. Wright. 2007. Current and potential U.S. corn stover supplies. Agron. J. 99:1-11.

Halvorson, A.D., and J.M.F. Johnson. 2009. Irrigated corn cob production in the Central Great Plains. Agron. J. 101:390-399.

Halvorson, A.D., and C.A. Reule. 2007. Irrigated, no-till corn and barley response to nitrogen in northern Colorado. Agron. J. 99:1521-1529.

Hatch, L.K., A. Mallawatantri, D. Wheeler, A. Gleason, D. Mulla, J. Perry, K.W. Easter, R. Smith, L. Gerlach, and P. Brezonik. 2001. Land management at the major watershed-agroecoregion intersection. J. Soil Water Conserv. 56(1):44-51.
Hatfield, J.L., T.J. Sauer, and J.H. Prueger. 2001. Managing soils to achieve greater water use efficiency: A review. Agron. J. 93:271-280.

Heaton, E., T. Voigt, and S.P. Long. 2004. A quantitative review comparing the yields of two candidate $C 4$ perennial biomass crops in relation to nitrogen, temperature and water. Biomass Bioenergy 27:21-30.

Heaton, E.A., F.G. Dohleman, and S.P. Long. 2008. Meeting U.S. biofuel goals with less land: The potential of Miscanthus. Global Change Biol. 14:2000-2014.

Hoskinson, R.L., D.L. Karlen, S.J. Birrell, C.W. Radtke, and W.W. Wilhelm. 2007. Engineering, nutrient removal, and feedstock conversion evaluations of four corn stover harvest scenarios. Biomass Bioenergy 31:126-136.

Hudson, B.D. 1994. Soil organic matter and available water capacity. J. Soil Water Conserv. 49:189-194.

Huggins, D.R., R.R. Allmaras, C.E. Clapp, J.A. Lamb, and G.W. Randall. 2007. Corn-soybean sequence and tillage effects on soil carbon dynamics and storage. Soil Sci. Soc. Am. J. 71:145-154.

Izaurralde, R.C. J.R. Williams, W.B. McGill, N.J. Rosenberg, and M.C.Q. Jakas. 2006. Simulating soil C dynamics with EPIC: Model description and testing against long-term data. Ecol. Modell. 192:362-384.

Jasinskas, A., A. Zaltauskas, and A. Kryzeviciene. 2008. The investigation of growing and using of tall perennial grasses as energy crops. Biomass Bioenergy 32:981-987.

Jawson, M.D., and L.F. Elliott. 1986. Carbon and nitrogen transformation wheat straw and root decomposition. Soil Biol. Biochem. 18:15-22.

Johnson, J.M.F., R.R. Allmaras, and D.C. Reicosky. 2006a. Estimating source carbon from crop residues, roots and rhizodeposits using the national grain-yield database. Agron. J. 98:622-636.

Johnson, J.M.F., N.W. Barbour, and S.L. Weyers. 2007a. Chemical composition of crop biomass impacts its decomposition. Soil Sci. Soc. Am. J. 71:155-162.

Johnson, J.M.F., M.D. Coleman, R.W. Gesch, A.A. Jaradat, R. Mitchell, D.C. Reicosky, and W.W. Wilhelm. 2007b. Biomass-bioenergy crops in the United States: A changing paradigm. The Americas J. Plant Sci. Biotechnol. 1:1-28.

Johnson, J.M.F., A.J. Franzluebbers, S.L. Weyers, and D.C. Reicosky. 2007c. Agricultural opportunities to mitigate greenhouse gas emissions. Environ. Pollut. 150:107-124.

Johnson, J.M.F., D.C. Reicosky, R.R. Allmaras, D. Archer, and W.W. Wilhelm. 2006b. A matter of balance: Conservation and renewable energy. J. Soil Water Conserv. 61(4):120A-125A.

Johnson, P.A., and B.J. Chamber. 1996. Effects of husbandry on soil organic matter. Soil Use Manage. 13:102-103.

Kaewpradit, W., B. Toomsan, P. Vityakon, V. Limpinuntana, P. Saenjan, S. Jogloy, A. Patanothai, and G. Cadisch. 2008. Regulating mineral N release and greenhouse gas emissions by mixing groundnut residues and rice straw under field conditions. Eur. J. Soil Sci. 59:640-652

Kapkiyai, J.J., N.K. Karanja, J.N. Qureshi, P.C. Smithson, and P.L. Woomer. 1999. Soil organic matter and nutrient dynamics in a Kenyan nitisol under long-term fertilizer and organic input management. Soil Biol. Biochem. 31:1773-1782.

Katterer, T., O. Andren, and R. Pettersson. 1998. Growth and nitrogen dynamics of reed canarygrass (Phalaris arundinacea L.) subjected to daily fertilization and irrigation in the field. Field Crops Res. 55:153-164.

Khanna, M., B. Dhungana, and J. Clifton-Brown. 2008. Costs of producing miscanthus and switchgrass for bioenergy in Illinois. Biomass Bioenergy 32:482-493.

Khosla, R., K. Fleming, J.A. Delgado, T.M. Shaver, and D.G. Westfall. 2002. Use of site-specific management 
zones to improve nitrogen management for precision agriculture. J. Soil Water Conserv. 57:513-518.

Kitchen, N.R., K.A. Sudduth, D.B. Myers, R.E. Massey, E.J. Sadler, R.N. Lerch, J.W. Hummel, and H.L. Palm. 2005. Development of a conservation-oriented precision agriculture system: Crop production assessment and plan implementation. J. Soil Water Conserv. 60(6):421-430.

Knapp, S.J., and J.M. Crane. 2000. Registration of reduced shattering cuphea germplasm PSR23. Crop Sci. 41:299-300.

Kong, A.Y.Y., J. Six, D.C. Bryant, R.F. Denison, and C. van Kessel. 2005. The relationship between carbon input, aggregation, and soil organic carbon stabilization in sustainable cropping systems. Soil Sci. Soc. Am. J. 69:1078-1085.

Kundu, S., R. Bhattacharyya, V. Prakash, B.N. Ghosh, and H.S. Gupta. 2007. Carbon sequestration and relationship between carbon addition and storage under rainfed soybean-wheat rotation in a sandy loam soil of the Indian Himalayas. Soil Tillage Res. 92:87-95.

Kushwaha, C.P., S.K. Tripathi, and K.P. Singh. 2000. Variations in soil microbial biomass and $\mathrm{N}$ availability due to residue and tillage management in a dryland rice agroecosystem. Soil Tillage Res. 56:153-166.

Lal, R. 2004. Is crop residue a waste? J. Soil Water Conserv. 59:136-139.

Lal, R. 2008. Crop residues as soil amendments and feedstock for bioethanol production. Waste Manag. 28:747-758.

Larson, J.A., B.C. English, and L. He. 2008. Risk and return for bioenergy crops under alternative contracting arrangements. Southern Agric. Econ. Assoc. Ann. Meet., Dallas, TX. 2-6 Feb. 2008. Available at http://ageconsearch.umn.edu/bitstream/6842/2/ sp08la02.pdf (verified 17 Sept. 2010).

Lee, D.K., and A. Boe. 2005. Biomass production of switchgrass in Central South Dakota. Crop Sci. 45:2583-2590.

Lee, D.K., V.N. Owens, and J.J. Doolittle. 2007. Switchgrass and soil carbon sequestration response to ammonium nitrate, manure, and harvest frequency on Conservation Reserve Program land. Agron. J. 99:462-468.

Lemus, R., E.C. Brummer, K.J. Moore, N.E. Molstad, C.L. Burras, and M.F. Barker. 2002. Biomass yield and quality of 20 switchgrass populations in southern Iowa, USA. Biomass Bioenergy 23:433-442.

Lemus, R., E.C. Brummer, C.L. Burras, K.J. Moore, M.F. Barker, and N.E. Molstad. 2008. Effects of nitrogen fertilization on biomass yield and quality in large fields of established switchgrass in southern Iowa, USA. Biomass Bioenergy 32:1187-1194.

Lewandowski, I., and A. Kicherem. 1997. Combustion quality of biomass: Practical relevance and experiments to modify the biomass quality of Miscanthus $x$ giganteus. Eur. J. Agron. 6:163-177.

Liebig, M., M. Schmer, K. Vogel and R. Mitchell. 2008. Soil carbon storage by switchgrass grown for bioenergy. BioEnergy Res. 1:215-222.

Liebig, M.A., H.A. Johnson, J.D. Hanson, and A.B. Frank. 2005. Soil carbon under switchgrass stands and cultivated cropland. Biomass Bioenergy 28:347-354.

Lindstrom, M.J. 1986. Effects of residue harvesting on water runoff, soil erosion and nutrient loss. Agric Ecosyst. Environ. 16:103-112.

Linquist, B.A., V. Phengsouvanna, and P. Sengxue. 2007. Benefits of organic residues and chemical fertilizer to productivity of rain-fed lowland rice and to soil nutrient balances. Nutr. Cycling Agroecosyst. 79:59-72.

Loeppky, H.A., and B.E. Coulman. 2002. Crop residue removal and nitrogen fertilization affects seed production in meadow bromegrass. Agron. J. 94:450-454

Madakadze, I.C., K.A. Stewart, P.R. Peterson, B.E. Coulman, and D.L. Smith. 1999. Cutting frequency and nitrogen fertilization effects on yield and nitrogen concentration of switchgrass in a short season area. Crop Sci. 39:552-557.

Manlay, R. J.L. Chotte, D. Masse, JY. Laurent, and C. Feller. 2002. Carbon, nitrogen and phosphorus allocation in agro-ecosystems of a West African savanna III. Plant and soil components under continuous cultivation. Agric. Ecosyst. Environ. 88:249-269.

Mann, L., and V. Tolbert. 2000. Soil sustainability in renewable biomass plantings. Ambio 29:492-498.

McLaughlin, S.B., and L. Adams Kszos. 2005. Development of switchgrass (Panicum virgatum) as a bioenergy feedstock in the United States. Biomass Bioenergy 28:515-535

McLaughlin, S., and M. Walsh. 1998. Evaluating environmental consequences of producing herbaceous crops for bioenergy Biomass Bioenergy 14:317-324.

Mitchell, R., J. Webb, and R. Harrison. 2001. Crop residues can affect $\mathrm{N}$ leaching over at least two winters. Eur. J. Agron. 15:17-29.

Mkhabela, M.S., A. Madani, R. Gordon, D. Burton, D. Cudmore, A. Elmi, and W. Hart. 2008. Gaseous and leaching nitrogen losses from no-tillage and conventional tillage systems following surface application of cattle manure. Soil Tillage Res. 98:187-199.

Moebius-Clune, B.N., H.M. van Es, O.J. Idowu, R.R. Schindelbeck, D.J. Moebius-Clune, D.W. Wolfe, G.S. Abawi, J.E. Thies, B.K. Gugino, and R. Lucey. 2008. Long-term effects of harvesting maize stover and tillage on soil quality. Soil Sci. Soc. Am. J. 72:960-969.

Monti, A., N. Di Virgilio, and G. Venturi. 2008. Mineral composition and ash content of six major energy crops. Biomass Bioenergy 32:216-223.

Moser, L.E., and K.P. Vogel. 1995. Switchgrass, big bluestem, and indiangrass. p. 409-420. In R.F. Barnes et al. (ed.) Forages, Vol. 1: An Introduction to grassland agriculture. Iowa State Univ. Press, Ames, IA

Mulkey, V.R., V.N. Owens, and D.K. Lee. 2006. Management of switchgrass-dominated conservation reserve program lands for biomass production in South Dakota. Crop Sci. 46:712-720.

Mulkey, V.R., V.N. Owens, and D.K. Lee. 2008. Management of warm-season grass mixtures for biomass production in South Dakota USA. Bioresour. Technol. 99:609-617.

Nelson, R.G., J.C. Ascough II, and M.R. Langemeier. 2006. Environmental and economic analysis of switchgrass production for water quality improvement in northeast Kansas. J. Environ. Manage. 79:336-347.

Nicholson, F.A., B.J. Chambers, A.R. Mills, and P.J. Strachan. 1997. Effects of repeated straw incorporation on crop fertiliser nitrogen requirements, soil mineral nitrogen and nitrate leaching losses. Soil Use Manage. 13:136-142.

Nyakatawa, E.Z., D.A. Mays, V.R. Tolbert, T.H. Green, and L. Bingham. 2006. Runoff, sediment, nitrogen, and phosphorus losses from agricultural land converted to sweetgum and switchgrass bioenergy feedstock production in north Alabama. Biomass Bioenergy 30:655-664.

Nyoka, B. 2007. Management guide for feedstock production from switchgrass in the northern Great Plains. Available at http://ncsungrant.sdstate.org/uploads/ publications/SGINC2-07.pdf (verified 17 Sept. 2010) North Central Sun Grant Center, South Dakota State Univ., Brookings.

Oschwald, W.R., M. Stelly, D.M. Kral, and J.H. Nauseef (ed.). 1978. Crop residue management systems. ASA Spec. Pub. 31. ASA, CSSA, and SSSA, Madison, WI.

Owens, S.R. 2007. Reduce Cooling Tower Water Consumption by 20 Percent. Available at http://ethanolproducer.com/article.jsp?article_id=3030 (posted June, 2007; verified 17 Sept. 2010). Ethanol Producer Magazine, Grand Forks, ND.

Parrish, D.J., and J.H. Fike. 2005. The biology and agronomy of switchgrass for biofuels. Crit. Rev. Plant Sci. 24:423-459. 
Parton, W.J., J.W.B. Stewart, and C.V. Cole. 1988. Dynamics of C, N, P and S in grassland soils: A model. Biogeochemistry 5:109-131.

Perlack, R.D., L.L. Wright, A. Turhollow, R.L. Graham, B. Stokes, and D.C. Erbach. 2005. Biomass as feedstock for a bioenergy and bioproducts industry: The technical feasibility of a billion-ton annual supply. Available at http://www.eere.energy.gov/biomass/ pdfs/final_billionton_vision_report2.pdf (posted 15 Jul. 2005; verified 17 Sept. 2010). USDOE and USDA.

Perlack, R.D., and A. Turhollow. 2002. Assessment options for the collection, handling and storage of corn stover. Available at http://bioenergy.ornl.gov/ pdfs/ornltm-200244.pdf (posted Sept. 2002; verified 17 Sept. 2010). Oak Ridge Natl. Lab., USDOE.

Petrolia, D.R. 2008. The economics of harvesting and transporting corn stover for conversion to fuel ethanol: A case study for Minnesota. Biomass Bioenergy 32:603-612.

Pikul, J.L.J., J.M.F. Johnson, T.E. Schumacher, M. Vigil, and W.E. Riedell. 2008. Change in surface soil carbon under rotated corn in eastern South Dakota. Soil Sci. Soc. Am. J. 72:1738-1744

Pordesimo, L.O., W.C. Edens, and S. Sokhansanj. 2004. Distribution of aboveground biomass in corn stover. Biomass Bioenergy 26:337-343.

Pordesimo, L.O., B.R. Hames, S. Sokhansanj, and W.C. Edens. 2005. Variation in corn stover composition and energy content with crop maturity. Biomass Bioenergy 28:366-374.

Postel, S., and B. Richter. 2003. Rivers for life: Managing water for people and nature. Island Press, Washington, DC.

Putnam, D.H., J.T. Budin, L.A. Field, and W.M. Breene. 1993. Camelina: A promising low-input oilseed. p. 314-322. In J. Janick and J. E. Simon (ed.) New crops John Wiley \& Sons, New York.

Rao, S.C., H.S. Mayeux, and B.K. Northup. 2005. Performance of forage soybean in the southern Great Plains. Crop Sci. 45:1973-1977.

Reicosky, D.C., and F. Forcella. 1998. Cover crops and soil quality interactions in agroecosystems. J. Soil Water Conserv. 53:224-229.

Reijnders, L. 2006. Conditions for the sustainability of biomass based fuel use. Energy Policy 34:863-876.

Reynolds, J.H., C.L. Walker, and M.J. Kirchner. 2000 Nitrogen removal in switchgrass biomass under two harvest systems. Biomass Bioenergy 19:281-286.

Rickman, R.W., C.L. Douglas, S.L. Albrecht, L.G. Bundy, and J.L. Berc. 2001. CQESTR: A model to estimate carbon sequestration in agricultural soils. J. Soil Water Conserv. 56:237-242

Robert, P.C. 2002. Precision agriculture: A challenge for crop nutrition management. Plant Soil 247:143-149.

Roldan, A., F. Caravaca, M.T. Hernandez, C. Garcia, C. Sanchez-Brito, M. Velasquez, and M. Tiscareno. 2003. No-tillage, crop residue additions, and legume cover cropping effects on soil quality characteristics under maize in Patzcuaro watershed. Soil Tillage Res. 72:65-73.

Saffigna, P.G., D.S. Powlson, P.C. Brookes, and G.A. Thomas. 1989. Influence of sorghum residues and tillage on soil organic matter and soil microbial biomass in an Australian Vertisol. Soil Biol. Biochem. 21:759-765.

Sainju, U.M., A. Lenssen, T. Caesar-Thonthat, and J. Waddell. 2006a. Carbon sequestration in dryland soils and plant residue as influenced by tillage and crop rotation. J. Environ. Qual. 35:1341-1347.

Sainju, U.M., A. Lenssen, T. Caesar-Thonthat, and J. Waddell. 2006b. Tillage and crop rotation effects on dryland soil and residue carbon and nitrogen. Soil Sci. Soc. Am. J. 70:668-678.

Salinas-Garcia, J.R., A.D. Baez-Gonzalez, M. TiscarenoLopez, and E. Rosales-Robles. 2001. Residue removal and tillage interaction effects on soil properties under rain-fed corn production in Central Mexico. Soil Tillage Res. 59:67-79.

Sanderson, M.A., R.L. Reed, S.B. McLaughlin, S.D. Wullschleger, B.V. Conger, D.J. Parrish, D.D. Wolf, C. Taliaferro, A.A. Hopkins, W.R. Ocumpaugh, M.A Hussey, J.C. Read, and C.R. Tischler. 1996. Switchgrass as a sustainable bioenergy crop. Bioresour. Technol. 56:83-93.

Sarr, P.S., M. Khouma, M. Sene, A. Guisse, A.N. Badiane, and T. Yamakawa. 2008. Effect of pearl millet-cowpea cropping systems on nitrogen recovery, nitrogen use efficiency and biological fixation using the ${ }^{15} \mathrm{~N}$ tracer technique. Soil Sci. Plant Nutr. 54:142-147.

Schneider, U.A., and B.A. McCarl. 2003. Economic potential of biomass based fuels for greenhouse gas emission mitigation. Environ. Resour. Econ. 24:291-312.

Searchinger, T., R. Heimlich, R.A. Houghton, F. Dong A. Elobeid, J. Fabiosa, S. Tokgoz, D. Hayes, and T.-H. Yu. 2008. Use of U.S. croplands for biofuels increases greenhouse gases through emissions from land-use change. Science 319:1238-1240.

Shapouri, H., J.A. Duffield, and M. Wang. 2003. The energy balance of corn ethanol revisited. Trans. ASAE 46:959-968.

Sheehan, J., A. Aden, K. Paustian, K. Killian, J. Brenner, M. Walsh, and R. Nelson. 2004. Energy and environmental aspects of using corn stover for fuel ethanol. J. Ind. Ecol. 7:117-146.

Shinners, K.J., B.N. Binversie, R.E. Muck, and P.J. Weimer. 2007. Comparison of wet and dry corn stover harvest and storage. Biomass Bioenergy 31:211-221.

Siemens, J.C., and W.R. Oschwald. 1978. Corn-soybean tillage systems: Erosion control, effects on crop production, costs. Trans. ASAE 21:293-302.

Simpson, T.W., A.N. Sharpley, R.W. Howarth, H.W. Paerl, and K.R. Mankin. 2008. The new gold rush: Fueling ethanol production while protecting water quality. J. Environ. Qual. 37:318-324.

Singer, J.W. 2005. Small grain cover crops for corn and soybean. Available at http://www.extension.iastate. edu/Publications/PM1999.pdf (verified 17 Sept. 2010). Iowa State Univ., Ames.

Smika, D.E., and P.W. Unger. 1986. Effect of surface residues on soil water storage. Adv. Soil Sci. 5:111-138.

Smil, V. 1999. Crop Residues: Agriculture's largest harvest. Bioscience 49:299-308.

Stocking, M.A. 1988. Assessing vegetative cover and management effects. p. 211-234. In R. Lal (ed.) Soil erosion research methods. Soil Water Conserv. Soc., Ankeny, IA.

Syers, J.K. 1997. Managing soils for long-term productivity. Philos. Trans. R. Soc. Lond. B Biol. Sci. 352:1011-1021.

Teel, A., S. Barnhart, and G. Miller. 2003. Management guide for the production of switchgrass for biomass fuel in Southern Iowa. PM 1710. Available at http:// www.extension.iastate.edu/Publications/PM1710.pdf (posted May 2003; verified 17 Sept. 2010). Iowa State Univ., Ames.

Thorup-Kristensen, K., J. Magid, and L.S. Jensen. 2003. Catch crops and green manures as biological tools in nitrogen management in temperate zones. Adv. Agron. 79:227-302.

Tian, G., B.T. Kang, and L. Brussand. 1992. Biological effects of plant residues with contrasting chemical composition under humid tropical conditions-Decomposition and nutrient release. Soil Biol. Biochem. 24:1051-1060.

Tian, L., J.F. Reid, and J.W. Hummel. 1999. Development of a precision sprayer for site-specific weed management. Trans. ASAE 42:893-900.

Tirol-Padre, A., K. Tsuchiya, K. Inubushi, and J.K. Ladha. 2005. Enhancing Soil Quality through Residue Man- 
agement in a Rice-Wheat System in Fukuoka, Japan. Soil Sci. Plant Nutr. 51:849-860.

Tomer, M.D., D.W. Meek, and L.A. Kramer. 2005. Agricultural practices influence flow regimes of headwater streams in western Iowa. J. Environ. Qual. 34:1547-1558.

Treier, K.E., M.H. Wicks, and D.M. Keener. 2006. Analysis of shelled corn as an agri-fuel-direct combustion vs. ethanol. ASABE Paper No. 066027. p. 1-12 In ASABE Annu. Intl. Meet. Am. Soc. of Agric. and Biol. Eng., Portland, OR. 9-12 July 2006. ASABE, St. Joseph, MI,

Uhlenbrook, S. 2007. Biofuel and water cycle dynamics: What are the related challenges for hydrological processes research? Hydrol. Processes 21:3647-3650.

Unger, P.W., and M.F. Vigil. 1998. Cover crop effects on soil water relationships. J. Soil Water Conserv. 53:200-207.

USDA-NRCS. 2002. National Agronomy Manual. 190 V-NAM. 3rd ed. USDA, Washington, DC.

USDA-NRCS. 2006. Soil conservation brief: Soil quality. No. 0601. Available at http://www.nrcs.usda.gov/feature/outlook/Soil\%20Quality.pdf (posted Feb. 2006; verified 17 Sept. 2010). USDA-National Resource Conservation Service.

Varvel, G.E., K.P. Vogel, R.B. Mitchell, R.F. Follett, and J.M. Kimble. 2008. Comparison of corn and switchgrass on marginal soils for bioenergy. Biomass Bioenergy 32:18-21.

Varvel, G.E., and W.W. Wilhelm. 2008a. Soil carbon levels in irrigated western Corn Belt rotations. Agron. J. 100:1180-1184.

Varvel, G.E., and W.W. Wilhelm. 2008b. Cob biomass production in the western Corn Belt. BioEnergy Res. 1:223-228.

Velthof, G.L., P.J. Kuikman, and O. Oenema. 2002. Nitrous oxide emission from soils amended with crop residues. Nutr. Cycling Agroecosyst. 62:249-261.

Vogel, K.P., J.J. Brejda, D.T. Walters, and D.R. Buxton. 2002. Switchgrass biomass production in the Midwest USA: Harvest and nitrogen management. Agron. J. 94:413-420.

Vogel, K.P., J.F. Pedersen, S.D. Masterson, and J.J. Toy. 1999 Evaluation of a filter bag system for NDF, ADF, and IVDMD forage analysis. Crop Sci. 39:276-279.

Wells, R.R., D.A. DiCarlo, T.S. Steenhuis, J.Y. Parlange, M.J.M. Römkens, and S.N. Prasad. 2003. Infiltration and surface geometry features of a swelling soil following successive simulated rainstorms. Soil Sci. Soc. Am. J. 67:1344-1351.

Wilhelm, W.W., J.W. Doran, and J.F. Power. 1986. Corn and soybean yield response to crop management under no-tillage production systems. Agron. J. 7:184-189.

Wilhelm, W.W., J.M.F. Johnson, J.L. Hatfield, W.B Voorhees, and D.R. Linden. 2004. Crop and soil productivity response to corn residue removal: A literature review. Agron. J. 96:1-17.

Wilhelm, W.W., J.M.F. Johnson, D.L. Karlen, and D.T Lightle. 2007. Corn stover to sustain soil organic carbon further constrains biomass supply. Agron. J. 99:1665-1667.

Wilhelm, W.W., J.M.F. Johnson, D. Lightle, N.W. Barbour, D.L. Karlen, D.A. Laird, J. Baker, T.E. Ochsner, J.M. Novak, A.D. Halvorson, D.W. Archer, and F. Arriaga. 2010. Vertical distribution of corn stover dry mass grown at several U.S. locations. BioEnergy Res. doi:10.1007/s12155-010-9097-z.

Wilson, G.V., S.M. Dabney, K.C. McGregor, and B.D. Barkoll. 2004. Tillage and residue effects on runoff and erosion dynamics. Trans. ASAE 47:119-128.

Wolf, D.D., and D.A. Fiske. 1996. Planting and managing switchgrass for forage, wildlife, and conservation. Publication No. 418-013. Available at http://pubs.ext. vt.edu/418/418-013/418-013.pdf (posted June, 1996; verified 17 Sept. 2010). Virginia Polytechnic Inst. and State Univ., Blacksburg.

Wright, L.L. 1994. Production technology status of woody and herbaceous crops. Biomass Bioenergy 3:191-210.

Ying, J., S. Peng, G. Yang, N. Zhou, R.M. Visperas, and K.G. Cassman. 1998. Comparison of high-yield rice in tropical and subtropical environments: II. Nitrogen accumulation and utilization efficiency. Field Crops Res. 57:85-93.

Yu, F., R. Ruan, and P. Steele. 2008. Consecutive reaction model for the pyrolysis of corn cob. Trans. ASABE 51:1023-1028.

Zemenchik, R.A., and K.A. Albrecht. 2002. Nitrogen use efficiency and apparent nitrogen recovery of Kentucky bluegrass, smooth bromegrass, and orchardgrass. Agron. J. 94:421-428.

Zhang, N., M. Wang, and N. Wang. 2002. Precision agriculture-a worldwide overview. Comput. Electron. Agric. 36:113-132. 